\title{
Learnings from Local Collaborative Transformations: Setting a Basis for a Sustainability Framework
}

\author{
Pedro Macedo ${ }^{1, *} \mathbb{0}$, Ana Huertas ${ }^{2}$, Cristiano Bottone ${ }^{2}$, Juan del Río ${ }^{2}$, Nicola Hillary ${ }^{3}$, \\ Tommaso Brazzini ${ }^{2}$, Julia M. Wittmayer ${ }^{4}\left(\right.$ ) and Gil Penha-Lopes ${ }^{1}$ \\ 1 Centre for Ecology, Evolution and Environmental Changes, Faculdade de Ciências, Universidade de Lisboa, \\ 1749-016 Lisbon, Portugal; gppenha-lopes@fc.ul.pt \\ 2 Municipalities in Transition Project, Totnes TQ9 5HN, UK; anahuertas@reddetransicion.org (A.H.); \\ cristiano.bottone@transitionitalia.it (C.B.); juandelrio@reddetransicion.org (J.d.R.); \\ t.brazzini@gmail.com (T.B.) \\ 3 Transition Network, Totnes TQ9 5HN, UK; nicolahillary@transitionnetwork.org \\ 4 Dutch Research Institute of Transitions, Erasmus University Rotterdam, 3062 PA Rotterdam, \\ The Netherlands; j.m.wittmayer@drift.eur.nl \\ * Correspondence: pamacedo@fc.ul.pt; Tel.: +351-936061160
}

Received: 16 December 2019; Accepted: 18 January 2020; Published: 21 January 2020

\begin{abstract}
The complexity of the sustainability challenge demands for collaboration between different actors, be they governments, businesses, or grassroots movements, at all levels. Nevertheless, and according to previous research, many tensions and obstacles to partnership still exist and results are far from meaningful. By investigating potential synergies, our purpose is to define a sustainability framework to promote better collaboration between community-based initiatives and local governments, in the context of transformation. Specifically, the research aim presented in this paper is to harvest learnings from existing collaborative experiments at the municipal level. As a starting point and using exploratory literature review concerning areas like policy (e.g., public administration) or business and management research, we propose a 'Compass for Collaborative Transformation'. This heuristic device can support the study of these sustainability experiments. We also introduce a method to map the governance imprint of these collaborations and to provide a 'proxy' of transformative efforts. We then present and discuss results from 71 surveyed cases happening in 16 countries in America and Europe, comparing distinctive frameworks involved. Finally, we consider the preconditions of a framework to improve these local collaborations-namely the capacity to support joint navigation through transformative efforts, facing high levels of uncertainty and complexity—and present ongoing efforts to codesign a new sustainability framework.
\end{abstract}

Keywords: collaboration; governance; framework; local government; community-based initiative; sustainability; transformation

\section{Introduction}

The reasons behind the need for a deep change in our societies are well iterated and include climate change and other consequences of crossing planetary boundaries, e.g., [1]. Nevertheless, like others, e.g., [2] (p. 2), we consider that facing limits, such as planetary boundaries, is an opportunity to reimagine society and that we should embrace transformation as our watchword.

The complexity of this challenge demands for collaboration between different organizations, be they states, businesses, or civil society [3], translating into the capacity of its members to collectively set and pursue shared goals [4]. This collaboration is expected to happen across levels [5] (p. 85) with the local context becoming an effective space for engaging citizens and organizations since they are directly affected by decisions and the impact of (in)action. 
In fact, a growing field of transformation research is dedicating its efforts to sustainability challenges [6-8]. While, Patterson and colleagues [9] conclude that there is the need to "place governance and politics at the center of research on transformations towards sustainability," Abson and colleagues [10] accentuate the urgency to "identify solution-oriented approaches to transformational change" also [11]. The present research tries to face these challenges by focusing on local collaborative transformations that might be the basis for an innovative process leading to a more sustainable society. The research aim is to develop practical knowledge rather than epistemic, in a phronesis approach [12].

We try to face the general question: How can we generate, in practice, local action that can potentially create global positive transformation in an effective and efficient way? Surely many solutions have already been explored and there is not one single answer. What (possibly) makes this research distinct is the starting point: We assume that a great potential for transformation rests in the joint action between local authorities and civil society. Our approach is to conceptualize and empirically explore the dynamic interactions between these local actors in the contexts they are embedded [13].

The assumed research question is therefore how to promote synergies between local governments and community-based initiatives in their pursuits of (local) sustainability. A key feature is that it is not looking for a new 'recipe' for promoting local collaborations but instead a sustainability framework that can help existing collaborations to foster their transformative impact.

A participatory action research approach was decided, since it has proven to be valuable in supporting sustainability and transformative efforts at local level by mixing the production of knowledge and societal action [14].

The research developed included the creation of an assessment tool for local transformative collaborations, mapping and assessing 71 impactful collaborative cases in 16 countries, co-designing an agreed framework, testing and refining in pilots, promoting a community of practice and outreach.

In this paper we start by addressing the collaborative dynamics between local organizations (our unit of analyses), proposing a 'Compass for Collaborative Transformation' as an assessment tool (next section). Under 'methods' we present the research design and the methods used in harvesting and analyzing the existent 71 cases (case study research). The learnings from the cross-case analysis of the multi-actor governance networks are presented in the following section ('results'). In 'discussion' we arrive at the propositions for a sustainability framework to improve these local collaborations and present the ongoing efforts to codesign and test a new instrument to activate synergies. Finally, in 'conclusions,' we summarize the scientific contributions of this paper.

\section{Local Transformative Collaborations}

Collaboration is at the heart of natural evolution [15], including that of humans, and is considered a positive feature in cultures across the world without known exception [16], even though it might be losing ground towards competition [17]. Consequently, collaboration captures the attention of many research fields, from game theory [18] to strategic management [19], and is well studied under public administration [20]. Policy studies have shown that collaboration can mitigate conflict, therefore enabling collective action [21]. Partnerships, as collaborative arrangements, can also produce and catalyze synergies by way of pooling resources and skills [22].

However, we should also mention that collaboration is no panacea to advance governance [23]. As research showed extensively, collaborations are not easy tasks; they take time, effort, and resources, require working with complex human interactions around power relations, and do not necessarily lead to synergies and advantages [3,24]. They are inherently paradoxical [3] and contributions to sustainability lack evidence [25].

Several factors can influence the results of collaborations and have been reported in literature. In an effort to systematize these factors a 'Compass for Collaborative Transformation' is proposed (Figure 1). This heuristic was used in the research process as an assessment framework for existing experiences of transformative collaboration between local organizations. 


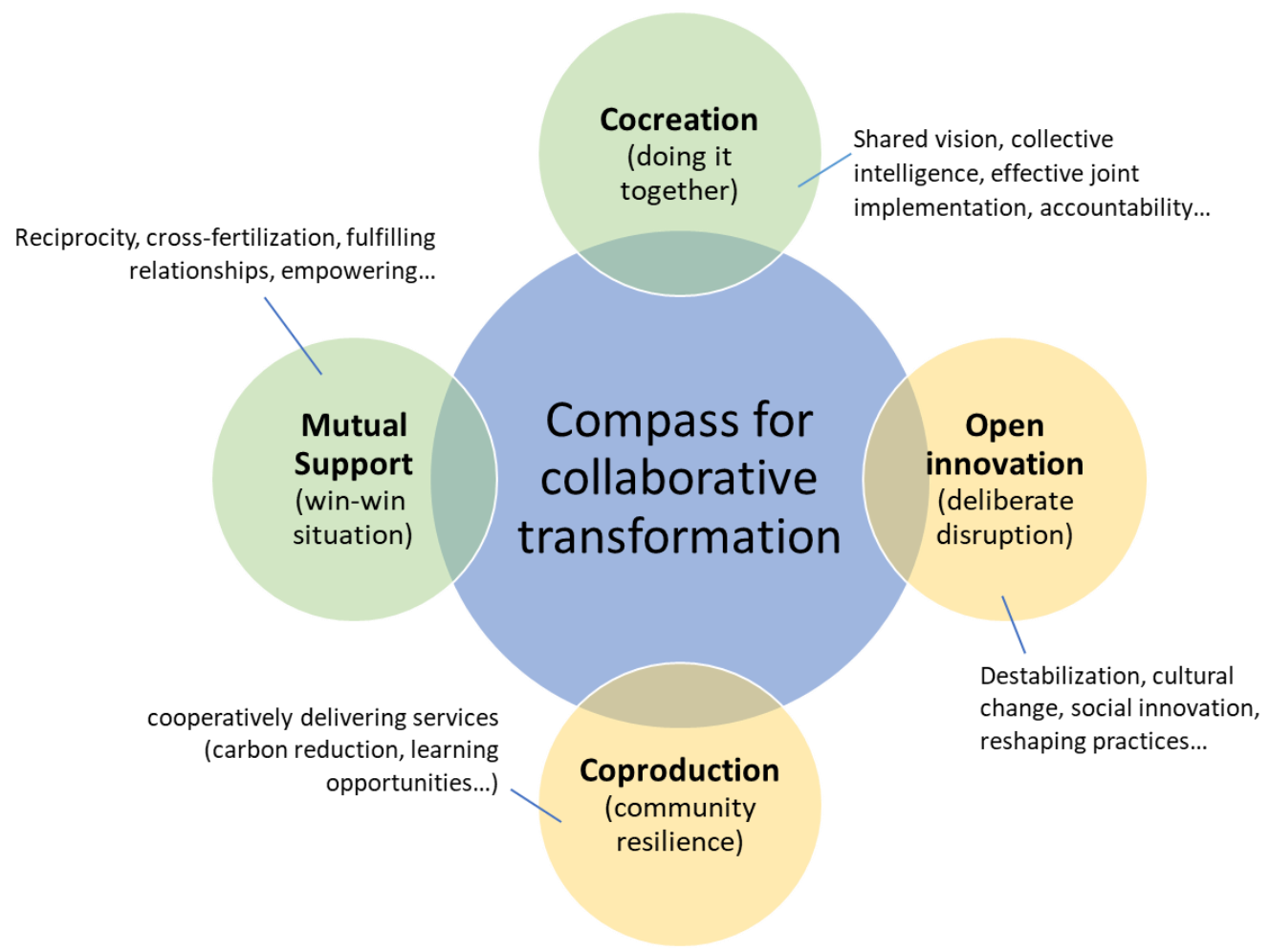

Figure 1. What makes a successful transformative collaboration? The 'Compass for Collaborative Transformation' allows a multidimensional assessment of collaborations between local governments and community-based initiatives, in terms of transformation towards sustainability. The green circles relate primarily to the quality of the process (cocreation) and relationships established (mutual support) and the yellows to outcomes, including concrete outputs (coproduction) and more intangible impacts (open innovation).

The first proposition advocates that local institutions should promote the cocreation of initiatives ('doing it together'), by making use of their collective intelligence. This can involve processes of collaborative envisioning, analyzing scenarios, and setting pathways [26-28]. Discussing and agreeing on a shared understanding and analyses of the problem, as well as long-term commitments, are considered critical [29]. Transition management, for instance, focuses on the role of a team of leaders in collaborative visioning and steering of experiments, combined with a reflexive approach that includes monitoring, evaluating, and learning [30-33]. Clearly defining complementary roles and taking joint decisions are also factors present in effective joint implementation processes. These efforts are expected to reinforce legitimacy [34], especially if aspects of inclusion, representativeness, transparency, and accountability are considered.

The second proposition highlights the need for mutual support with reciprocity in mind ('win-win situation'), leading to cross-fertilization, fulfilling relationships, and empowerment. Key conditions for fruitful collaborations are the commitment to work together and the development of trust [35]. Studies also show that funding can be important but not as much as creating spaces for permanent, enduring, structured, and interpersonal dialogue [36,37]. A suitable level of bureaucracy and formality is also critical to reduce the risk of phenomena like 'coercive isomorphism' [38], in which community-based initiatives are pressured to conform to requirements and expectations of incumbent regimes (e.g., to adopt a legal structure or fit within the parameters of the political agenda). In general, sharing goods and services or information and knowledge (e.g., two-way training), and also cross marketing (promoting and participating in each other's activities), are factors that can contribute positively. Fairness should be promoted by equally sharing risks, efforts, and benefits. 
The third proposition focuses on coproduction, namely the joint delivery of goods and services aiming at caring for people and the planet, thus promoting 'community resilience' [39]. The coproduction of (hopefully transformative) public services may be the decisive step in a collaboration between local governments and grassroots movements. Bovaird [40] concluded that supporting coproduction should be the "new public service ethos." In particular, the coproduction of goods and services by different actors organized into polycentric systems can be "crucial for achieving higher levels of welfare in developing countries, particularly for those who are poor" [41]. Some advances have occurred, especially in 'community energy' [42] and 'ecosystem stewardship' [43]. Coproduction might include the provision of well-being and personal growth (e.g., learning opportunities, community engagement); 'green' economy (e.g., entrepreneurship, localization, circularity); vibrant culture (e.g., local heritage, creativity); social capital (e.g., extent of networks, density of relationships); justice and equity (e.g., deliberate redistributive efforts, inclusion); ecological restoration; other sorts of climate mitigation and adaptation.

Finally, the fourth proposition addresses the need for open innovation, making transparent and explicit what is to be transformed and for whom, and promoting the destabilization of existing regimes. The idea of 'deliberate disruption' is a reaction to the urgency of tackling sustainability issues and the need for radical and 'deep' change, e.g., [44-46]. Several theories have been proposed to frame the more intangible outcomes, ranging from transformative social innovation [47], social learning [48], practices theory [49], technological innovation systems [50], narratives of change [51,52], institutionalization [53], cultural change [54], networked governance [55], etc. These follow from (sometimes) opposing ontologies [56]. Here the term 'open innovation' is used to emphasize the importance of using internal and external ideas in these collaborations [57].

\section{Methods}

By investigating the potential synergies between local organizations, our purpose is to find a framework to promote a better collaboration between community-based initiatives (CBIs) and local governments (LGs), in the context of transformation.

A participatory action research process was chosen since the main intention is to support practitioners in enhancing their impact by developing practical solutions $[58,59]$. These kinds of processes are particularly helpful in the context of sustainability-researchers engage in their social responsibility and assume the roles of change agents, knowledge brokers, (self)reflective scientists, and process facilitators [60].

A collaborative inquiry was set involving the Transition movement and the University of Lisbon, also anchored by their role within ECOLISE (European Network for Community-Led Initiatives on Climate Change and Sustainability). The work is integrated in the project 'Municipalities in Transition,' started in 2017.

The Transition movement is considered one of the most significant examples of local communities leading the way to a post-carbon society, at least in Europe [61-63]. These initiatives are spread world-wide and demonstrate a distinctive openness for collaborations [64]. They are, therefore, a pertinent and suitable starting point for the present research (that does not restrict itself to the Transition movement), providing an experimental space with transformational ambition [65] (p. 6). Nevertheless, a bias toward Western countries might be expected. It should also be considered that these experiments do not always reflect the diversity of the communities in which they thrive [66,67], despite their efforts on inclusivity [61].

Research included codesigning a framework that could be used to boost the transformative reach of cooperation between local actors of sustainability and testing and refining the framework in pilots. The experimentation process is presented elsewhere.

For the codesign we used a multi-method approach including literature review, an explorative analysis of 71 surveyed cases of local or regional collaborations happening in 16 countries in America and Europe, and transdisciplinary co-design sessions. 
With the aim of learning from the existing cases of transformative collaboration at local level, a two phase research was developed: (1) General harvesting by observation and questionnaires (to increase reach and get quantitative data); a snowball sampling was used starting from the Transition movement; and (2) in-depth study of eight selected cases using observation and semi-structured interviews to main stakeholders (to get detailed information and different points of view).

In phase 1, a snowball sampling was used starting from the list of Transition Hubs (national or regional networks within the Transition movement) and spreading to Transition initiatives and correspondent networks of practitioners, in a way to make good use of their resources and knowledge. Data was collected by people that participated in or observed cases where LGs were involved in exemplary and stable collaborative efforts with CBIs. Data collectors and cases were not necessarily linked to the Transition movement.

Data was collected through questionnaires (provided online) and related primarily to the dynamics between actors involved (our unit of analysis), including governance models and tools used to foster collaboration. In phase 2, interviews were performed to case participants (including one from the LG, one from the CBI, and a third person not involved in the case management, possibly a beneficiary or someone participating in the activities).

We used the 'Compass for Collaborative Transformation' (Figure 1) as an analytical framework for the interpretation of results. In order to examine the governance imprint of the local transformative collaborations we used a tool called 'Energy Function' [68], developed in Italy. Giving this methodology, the occurring processes can be mapped according to the actors involved and transformative actions developed in each case.

The Actors' categories used are:

- Municipality, political level: Who institutionally contributes to defining policies, e.g., council, commissions, parties

- Municipality, organizational structure: Technicians and other civil servants responsible for performing municipal functions

- Controlled entities: Entities that are in some way controlled by the municipality

- Suppliers: Public and private suppliers of the municipality

- Organizations: Economic, social, and cultural organizations, profit and non-profit (e.g., business, schools, environmental organizations)

- $\quad$ Public: Families and citizens

- Networks: Other municipalities and actors outside the territory (e.g., other municipalities, levels of government, partners in international networks)

And the Actions' categories:

- Vision: Actions and processes that tend to create a vision

- Organization: Actions and processes that tend to create or modify the governance, procedures, roles, and related issues (e.g., creating a new office to deal with sustainability issues)

- Planning: Actions and processes that tend to create a plan (e.g., setting goals, policies integrations, budgets)

- Technical aspects: Actions that modify the system through technology

- Relations: Actions and processes that want to create or improve relationships, namely acting on human and social aspects

- Cultural change: Actions and processes that aim to lead to a 'paradigm shift' (including communication and educational activities)

- Networking: Actions and processes that aim to create stable connections and comparisons (e.g., benchmarking)

The 'Energy Function' tool is part of a framework for dealing with the complex sustainability challenge and was one of the cases studied in this research. 
After setting the preconditions for a sustainability framework that could enhance synergies, a codesign process was developed using sociocratic techniques within the steering group (people from Transition Hubs and researcher from the University of Lisbon) and information from the case studies and literature.

\section{Results}

What can we learn from existing collaborative experiments at the municipal level? We will now present the research developed to answer this question.

Exemplary cases of local transformation were collected through an online survey sent to Transition Hubs in the beginning of July 2017. By the beginning of October 2017, 71 cases had been collected (see Appendix A), currently active in 16 countries: Belgium, Brazil, Chile, Colombia, Denmark, France, Germany, Hungary, Italy, Mexico, Netherlands, Portugal, Spain, Sweden, United Kingdom, and United States. Most of the cases were "well-established and running" (40), while some were still in design stage (10) or had just started (21).

Data was collected mainly by people connected with the Hubs (63\%) and/or Transition initiatives $(48 \%)$. Most of them state that they could be perceived as neutral to the cases, but some degree of bias is expected to occur.

The 71 cases collected were mostly located in urban context (around three-quarters) with population ranging from 200 to 12,000,000 (frequently between 1000 and 40,000). The main area of activity (multiple choice possible) was raising awareness $(77 \%)$. Cases also mostly dedicated themselves ( $>50 \%)$ to food and agriculture; education; participatory democracy; and planning and community work (Figure 2). Relating to beneficiaries, the cases were mostly aimed at a general public $(65 \%)$, followed by $(44-32 \%)$ adults, families, elders, young adults, teenagers, and children. Cases were also asked about assessment relating some of the main domains of the Compass (Figure 3).

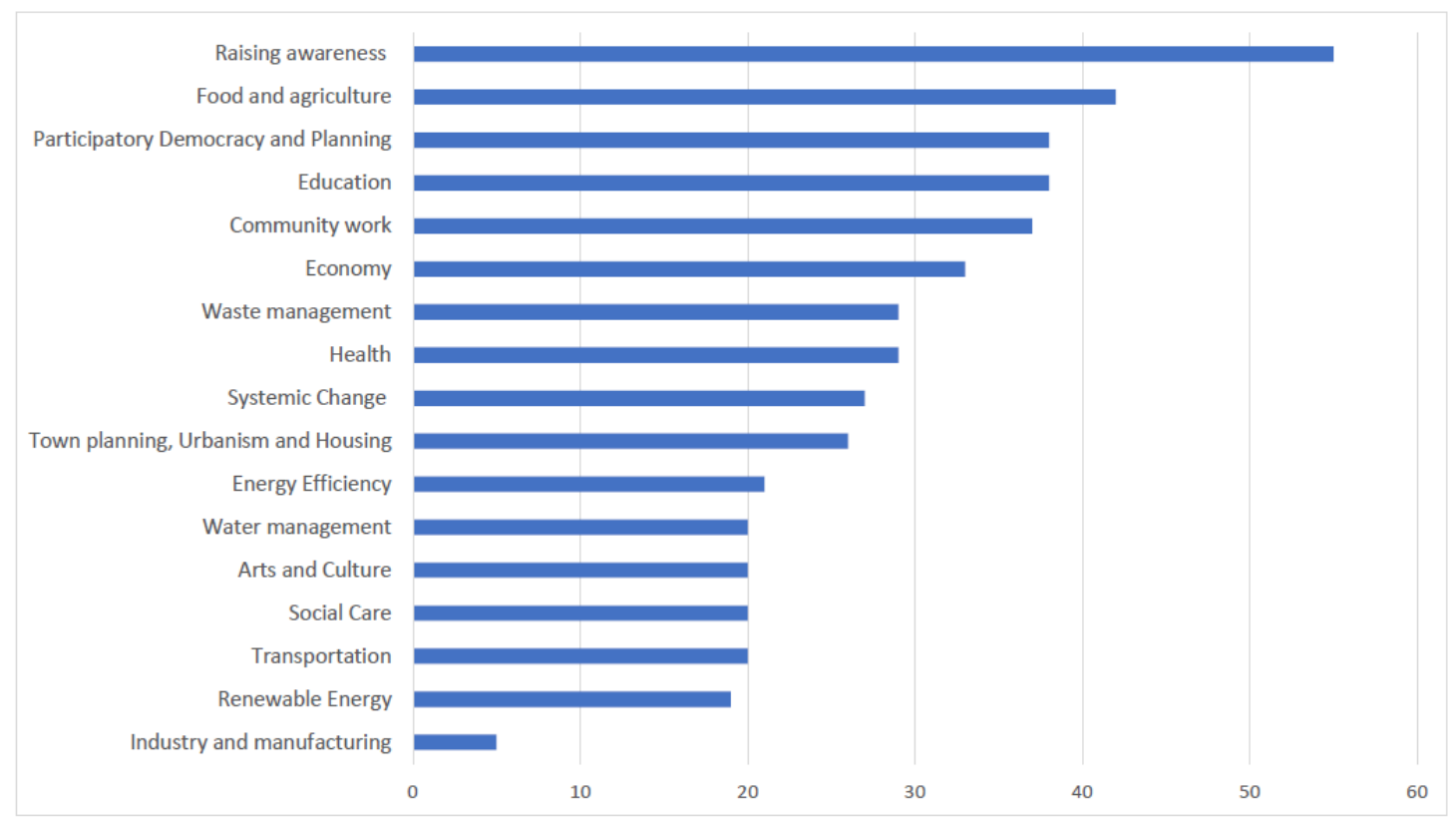

Figure 2. Results from the survey-main subjects that the case studies focus on $(n=71)$. 


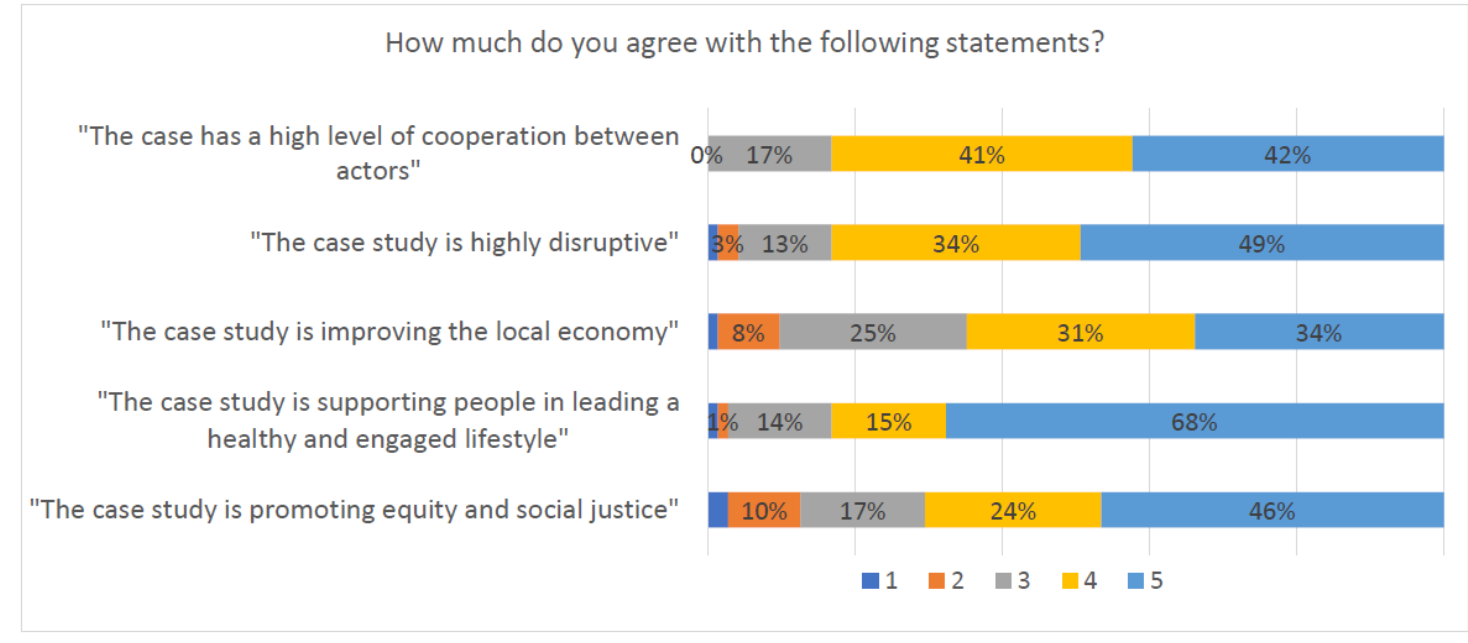

Figure 3. Results from the survey-answers to the question: "How much do you agree with the following statements?" ( 1 = Fully disagree; 5 = Fully agree).

According to the data collectors, cases exhibit a significant degree of innovation and cooperation between actors (Figure 3). This was expected since these were prerequisites for the selection. Cases are mostly focused in changing lifestyles and promoting justice.

In terms of climate change mitigation and adaptation, the initiatives stated that their contributions were mainly by institutional and behavioral change or reinforcement, followed by producing local and/or organic food and promoting healthy and sustainable diets, preventing waste and recycling (circular economy), promoting sustainable mobility (cycling, public transport, electric and shared cars), creating green infrastructures, and generating heat and electricity from renewable sources (Figure 4).

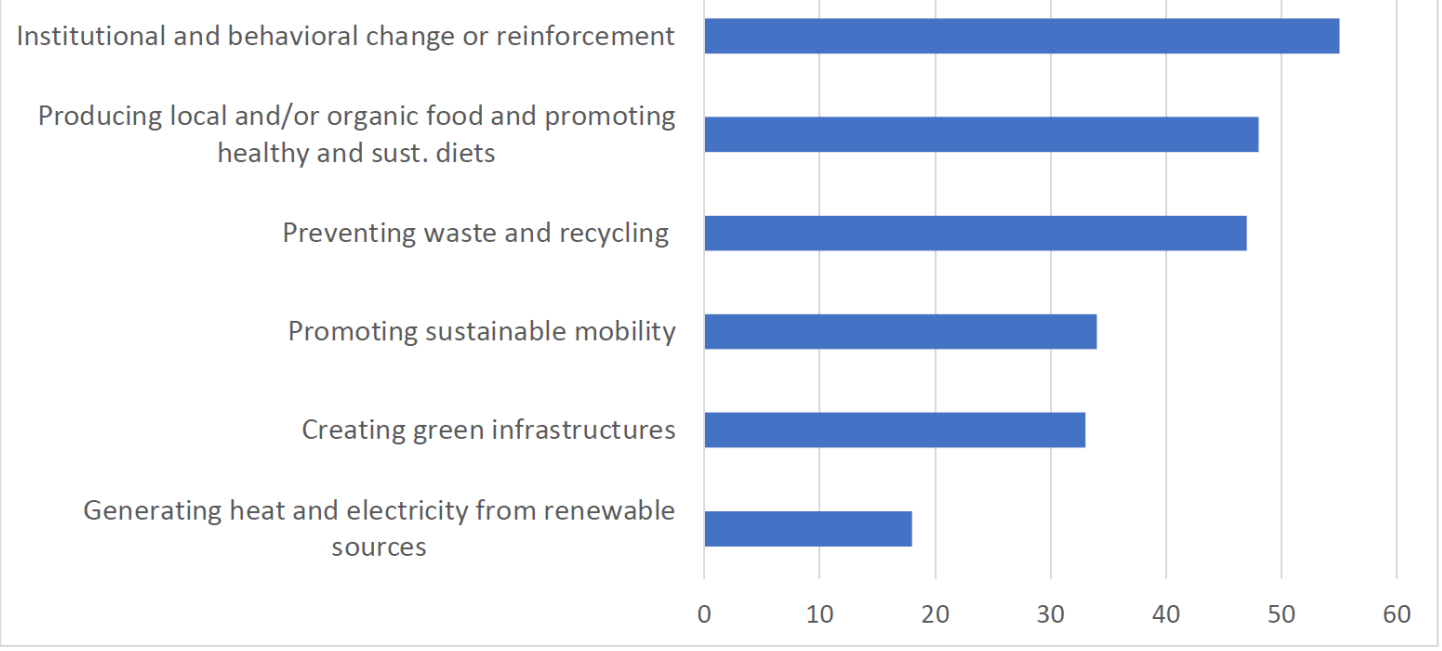

Figure 4. Results from the survey-Contributions to climate change mitigation and adaptation ( $\mathrm{n}=71)$.

Cases surveyed were quite diverse, including in their governance systems. They spanned from grassroots eco-neighborhoods in São Paulo to a well-structured transformation initiative at city level in Dresden with governmental support, an ecovillage in Colombia managed by women or cooperatives to produce energy and promote local food. Some cases focused on the collaborative promotion of concrete activities or topics (e.g., cycling, circular economy, urban agriculture) or more spiritual experiences (e.g., inner transition). 
In most of the cases it was possible to identify some progressiveness in the way that local governments and civil society work together with a transformative aim. Besides partnerships, spaces for dialogue and learning, action groups are quite common ('local innovation committee, 'neighborhood environmental committee,' 'neighborhood assemblies, 'schools of life,' 'living classrooms,' 'future city team') as well as the creation of networks connecting change agents.

Some of the tools used to promote transformative collaboration include sharing land and other resources, demonstrative centers, coworking spaces, convergence events, social currencies, distribution of small grants, shared social media platforms, ethnography approaches, communitarian management of public spaces, etc. Management tools like Dragon Dreaming, Sociocracy, Theory U and Nonviolent Communication are also used.

Most of the cases (73\%) have some connection to the Transition movement and several active collaborations with municipalities were presented. Most of the cases also reported that they belonged to some local, regional, national, or international network (e.g., Covenant of Mayors), while a few created their own networks. Funding comes from municipalities, private sector, cooperatives, non-governmental organizations, crowdfunding and users, besides other national and international levels (e.g., European Union).

The mapping of actors and actions involved for each case is presented in Table 1 and was produced through content analyses of the information collected.

Table 1. Mapping of the collected cases $(n=71)$ according to actors and actions involved. Higher values have been flagged in bold. Colored cells are considered 'leverage points.' Adapted from [68].

\begin{tabular}{|c|c|c|c|c|c|c|c|}
\hline \multirow[b]{2}{*}{$\begin{array}{c}\text { Actions } \\
\text { Categories }\end{array}$} & \multicolumn{7}{|c|}{ Actors Categories } \\
\hline & $\begin{array}{c}\text { Municipality } \\
\text { Political }\end{array}$ & $\begin{array}{c}\text { Municip. } \\
\text { Organization }\end{array}$ & $\begin{array}{c}\text { Controlled } \\
\text { Entities }\end{array}$ & Suppliers & Organizations & Public & Networks \\
\hline Vision & 24 & 18 & 2 & 1 & 35 & 24 & 6 \\
\hline Organization & 46 & 46 & 6 & 2 & 55 & 46 & 4 \\
\hline Planning & 26 & 22 & 2 & 1 & 32 & 22 & 6 \\
\hline Technical aspects & 15 & 19 & 4 & 2 & 34 & 25 & 3 \\
\hline Relations & 12 & 12 & 1 & 0 & 33 & 33 & 0 \\
\hline Cultural change & 35 & 36 & 5 & 1 & 62 & 63 & 8 \\
\hline Networking & 31 & 26 & 4 & 1 & 39 & 28 & 32 \\
\hline
\end{tabular}

The empirical observation of the Italian experience in using the 'Energy Function' shows that the crucial factors leading to real changes in the way a community organizes itself are new visions developed at the political level, planning occurring at the municipalities' organization level, and a cultural change at the public level. In the grid (Table 1) those cells have a 'higher' value (colored salmon). A second group of 'key' cells (colored orange) are considered as other activation areas with a high potential for change. For example, it is assumed that when organizations develop a new vision, change their culture, and plan accordingly we can observe an evolution in the community.

We can conclude that apparently the actors that are more actively involved in the cases (Figure 5) are organizations and the general public, followed by local governments. Controlled entities and suppliers are not usually mentioned which can demonstrate that initiatives like green procurement or life-cycle assessments are rare. Often, these controlled entities manage critical sectors relating to sustainability, like water, waste, or energy. 


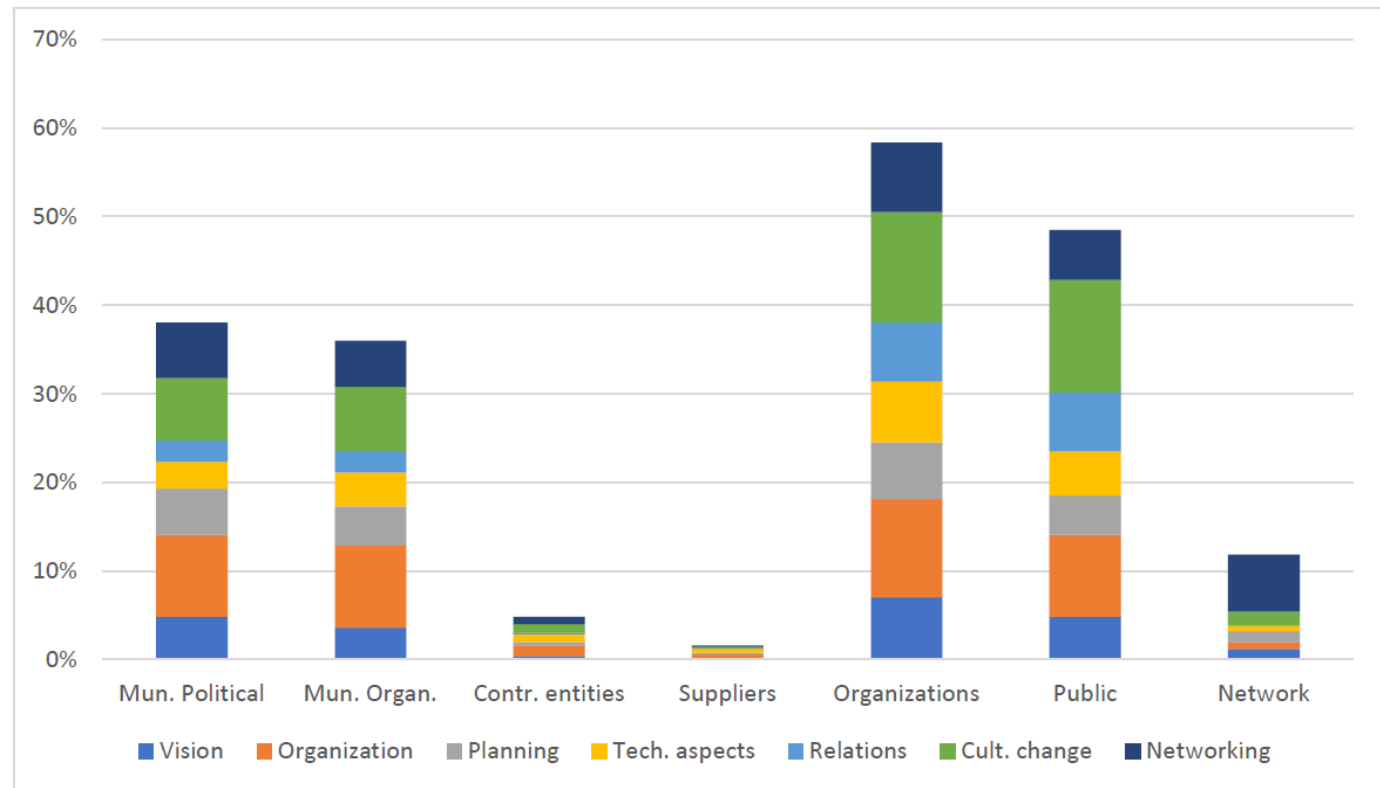

Figure 5. Frequency of actors' involvement in case studies, by actions' category.

Cultural change and new governance schemes (involving many actors) are the kind of goals most often pursued, followed by networking activities (Figure 6). Caring for relations looks like a less developed area of work. Visioning and planning can also be considered in relative deficit, taking into account the leverage power attributed to these activities.

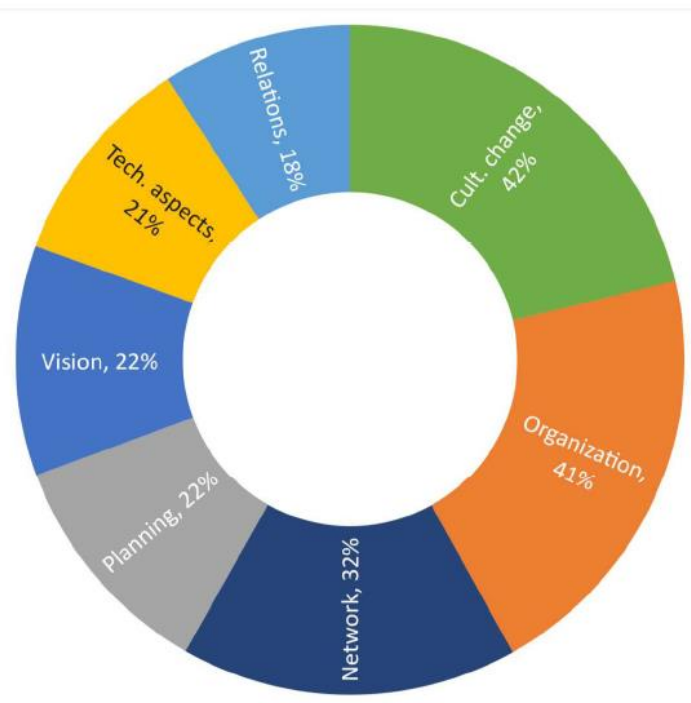

Figure 6. Relative frequency of actions in case studies.

A 'grid score' was produced for each case by counting the number of filled cells. A factor of 3 was applied to orange cells and 5 to salmon ('leverage cells'). The score varies between 6 and 59 (average $=26$ ), for a maximum value of 73 (see Appendix A). This score, we could argue, can be considered a proxy of the degree of transformative efforts happening in the community.

A multivariate analysis was performed but it did not allow to provide clear conclusions about possible case clusters. We should not forget to mention that lower values can correspond to cases where insufficient information is available and not necessarily cases with smaller impact. Therefore, in this context, it should not be considered a 'rank.' 


\subsection{Deeper Analysis of Eight Case Studies}

In order to select the cases to go through a deeper study, the following numerical data was used: (1) The 'grid score,' as a proxy of the degree of transformative efforts happening in the community; (2) cases' evaluation (Figure 5), namely the degree of cooperation between actors.

Final decision was made based on the steering group's subjective and consensual analyses of novelty and interest for research (this included a free discursive evaluation with a proposal on "how to proceed" prepared by each member, a voting process and debate). Cases with sectoral approaches or too context-specific were avoided. Location and population were also used as criteria in order to maximize the contextual diversity. Some cases were considered interesting as a 'tool' and not as a 'framework,' so a third phase on the research was decided in order to learn also from these cases.

Finally, eight cases were selected for in-depth study (Appendix B). All cases were "well-established and running" and were located in six geographical regions (Northern, Central and South America; Northern, Western, and Southern Europe). Half of them have concrete connections to the Transition movement. Overall the 'grid score' is comparatively high in the context of all the 71 cases.

Using the 'Compass for Collaborative Transformation' (Figure 1) as an assessment tool and focusing on the collaboration between LGs and CBIs, we can conclude that these cases provide quite valuable information.

\subsubsection{Cocreation}

For example, and looking at cocreation, the Ecobairro case in São Paulo started by civil society, drew on inputs from international networks and sustainability educators and designers from all over the world (through the Gaia Education training). But meanwhile a structured collaboration with the municipality was established based on a consultative and deliberative body, the Municipal Council for Environment and Sustainable Development (CADES). The Ecobairro had the opportunity to draft the CADES regulations and to participate in the strategy development (e.g., Strategic Master Plan, Zoning and Regional Plan linked to the Sustainable Development Goals) and effective joint implementation (e.g., green corridor for pollinators). In Jungapeo, Mexico, it was the local mayor that invited an NGO to cocreate a common initiative to establish the first official 'transition town' in Mexico. Efforts to share understanding and analyses of the problem are evident in cases like the Italian Energy Function (it might be considered the main goal) and MARES, Spain. The latter case is a good example of clearly defined and complementary roles, with collaboration happening between the municipality and consultants (previous experience of working together) and also collaborative platforms and citizens. It is also a case where formal monitoring and evaluation plays a key role. The same happens in Växjö, Sweden, and probably it is the main factor leading to success, also because the monitoring and evaluation comes from a clear purpose, common shared vision, and long-term commitments (although restricted to the political context). A similar clear visioning and pragmatic monitoring process occurs in Rubí, Spain, with collaborations between the municipality, schools, industries, and other agents. Here transparency and accountability are also clear key factors.

\subsubsection{Mutual Support}

Focusing on the dimension of 'mutual support,' we can highlight the case of Dresden, Germany. The municipality is putting their efforts into raising funds for civil society initiatives, and to support and train groups in using these resources. In Sonoma, United States of America, the Daily Acts NGO and municipalities are supporting each other, sharing educational skills and funds, and jointly resourcing civil society. In MARES the aim is also on providing access to assets and space (e.g., disused buildings) and sharing knowledge. Rubí uses a very clear approach to balance shared risks, efforts, and benefits, namely with the 50:50 partnerships between the municipality and schools (savings from energy use collaboratively achieved, are divided equally and reinvested with joint decisions). Cross marketing is a strategy used in Mexico to consolidate the collaboration: Members of the municipality are regularly 
invited and participate in workshops about Transition and related activities. The previously mentioned CADES, in Brazil, is a good example of a permanent space for dialogue, even though it faces the contingencies of political turnovers.

\subsubsection{Coproduction}

Coproduction efforts are significant in several cases. Daily Acts emphasizes social capital, putting great effort in developing networks. They also put emphasis on providing learning opportunities, like Jungapeo. Ecobairro also considers that the most significant contributions are on education, along with the generation of transformative public policies. MARES is equally generating social capital and learning opportunities, with a focus on equity. Rubí and the Energy Function focus on decarbonization, while Växjö looks mainly for environmental improvements. Collaboration between LGs and CBIs is expected to grow based on trust and confidence arriving from joint successful activities, as stressed in Jungapeo's case.

\subsubsection{Open Innovation}

The transformative potential is connected with reshaping practices (e.g., Rubí, Daily Acts or MARES) or mainly institutional change (e.g., Energy Function and Vaxjo). Energy Function also aims at cultural change, as well as Ecobairro ("culture of peace"), Jungapeo (autonomy) or others. Transformation through the creation of a networked governance is the underlying goal in Dresden's Future City. Daily Acts (and MARES) similarly account for the power of working with the entire ecosystems of actors and fostering networks of social innovation. They highlight how "large-scale social change happens through more collaborative approaches to scaling impact" and use tools like a Community Resilience Challenge. These efforts are expected to bring the emergence of widespread change. In Jungapeo they explicitly report the "outbreaks of spontaneous and orderly teamwork among the local population, as if the Transition Effect were contagious." Social learning can be, in fact, the main outcome of these cases.

Several cases have already manifested capacity for replicating. This is the case of Ecobairro, Daily Acts, and more significantly Rubí. In the latter, a political turnover in 2015 became a window of opportunity-the person in charge of the project left the municipality and joined a cooperative that spread the model to around 30 municipalities in Spain. The Rubís strategy on 100\% renewable sources of energy was also replicated by Catalan municipalities and others.

\section{Discussion}

According to some studies, collaboration between LGs and CBIs is happening in roughly half of the cases where local sustainability strategies are taking place $[69,70]$. It is considered a way to overcome common barriers [71] and deal with the increasing fragmentation in the social landscape [72]. In our research on exemplary cases we saw that collaboration delivers significant advantages which confirmed our assumption that a great potential for transformation rests in the joint action between local authorities and civil society. New models are already being advocated for [73] (p. 48).

The design of a new transformative framework that could boost these interactions started with case study research to collect knowledge from existing collaborations at local level. We collected and studied 71 cases happening in 16 countries, using observation, surveys, and interviews. A distinctive framework could be identified in 27 cases.

We used a 'Compass for Collaborative Transformation' (see Section 2) to go through a deeper analysis of eight selected case studies. This tool includes the dimensions considered as critical for assessing and developing effective collaborations between local institutions that meet the needs for transformation towards sustainability, namely, to be cocreated (using collective intelligence), taking care of relations (by mutual support), delivering goods and services that foster local resilience, and proving disruption relating to incumbent regimes. 
In their paper related to the evaluation of sustainability transitions, Turnheim and colleagues [74] express that, "in addition to the societal challenge, there is also a serious analytical challenge" and that we lack a practical approach that, "involve[s] the ability to capture analytically as robustly as possible the current state of transitions processes, through an assessment of the current scale, scope, and momentum of transitions".

To partially overcome this challenge, we used a grid (Table 1) that accommodates the transformative efforts that can be recognized as happening in the community. These initiatives occupy different cells in the grid corresponding to their categories (e.g., using new technologies or fostering relations) and the actors involved. We can therefore use the grid to get an overall perspective of the governance imprint of the change initiatives. The grid can be seen as an instrumental representation of the 'Arena of Development' concept proposed by Jørgensen [75]. It allows to interpret the changing relations and to capture the navigational strategies adopted by different actors [68].

Furthermore, it is possible to easily calculate a grid score that can be considered to provide a proxy of the degree of transformative efforts happening in the community. This measurement can be used to monitor and evaluate specific interventions and transformation as a whole, something that is considered to be a key theme related to societal transformation [12]. Here we should mark that the grid score might be non-significant when comparing different contexts.

\subsection{Preconditions for a Sustainability Framework}

Going back to our research question: What would be an effective framework to improve the existing local collaborative transformations by promoting synergies? From the empirical mapping exercise, we concluded that there is a great diversity of contexts and strategies in place. In many of them the resources are quite scarce. This led to the first preconditions of the framework being:

1. Easily adaptable to a wide variety of very different contexts

2. Simple enough to be relatively easy to learn and to use in real life

3. Low level of requirements for implementation

We also concluded that in the cases studied, power is distributed between local authorities and civil society in a similarly diverse and complex way. The power to take decisions and influence processes can concentrate in each one of the 'sides' or be 'equally' distributed. Also, many times this power balance is not evident or explicit, and often changes in time. The governance imprint of the change initiatives also makes evident the need for a relational perspective on transformative processes that supports the navigation in a field in flux.

Therefore, the following preconditions were added to the design requirements:

4. Suitable for use in a context of shared/diffused governance

5. Implementable both in top-down and bottom-up approaches

6. Support a relational perspective on sustainability

Ecopsychology bring us the notion that many people are overwhelmed with the complexity and enormity of crises like climate change, leading to anxiety, despair, and apathy [76]. This feeling of powerlessness and 'environmental melancholia' blocks vast resources of creative potential for engaging in change actions [77,78]. But even when we find ways to deal with these paralyzing concerns, we still must face with the complexity of solutions out here, including all the planning, technology innovations, changing lifestyles, or new social configurations. The 71 cases analyzed reflect this complexity, exhibiting the diversity of problems and solutions that we need to handle. They all exhibit the usefulness of strategies that promote collaboration in different dimensions (Figure 1).

Taking this into consideration, we add as further preconditions:

7. Powerful enough to cope with high levels of complexity and uncertainty

8. Make good use of existent tools and resources 
9. Able to hold the dimensions of cocreation, mutual support, coproduction, and open innovation.

This means that a sustainability framework is expected to be powerful enough to cope with the high levels of complexity and uncertainty and simultaneously simple and flexible enough to be relatively easy to learn and to use in real life. It should be based in a wide view on collaborative efforts and bring about a more relational perspective on sustainability.

\subsection{Basic Design}

Looking back to the cases mapped and the frameworks analyzed, we concluded that the Energy Function could match these preconditions and be used as a basis for design. In fact, this framework has been developed deductively and inductively in Italy, aiming at designing a model to provide guidance to municipalities in their transformation efforts, assuring great flexibility and organized tools regardless of the starting situation of the municipality. It takes into consideration that municipalities have similar structures but very different sizes and local contexts. By using this approach in analyzing the cases, we could also conclude that it is easy to use, still providing a useful overall picture of the spectrum of transformation. Additionally, as referenced in Table A2, the Energy Function is expected to include a database of operational tools that can be used in daily activities.

One of Energy Function's limitations was that it had not yet been significantly tested, although it was built on the experience of multiple municipalities. The creators [68] recognized that there was, "the need to configure a place, a group, a system... something able to follow the process, measure its effectiveness, understand its state of maturation, decide how (and if) to continue," and that, "partial answer will be found only by observing and supporting the experiences of the Municipalities that will be able to interpret, with regard to the territory and their community, the role of facilitators" (free translation).

A new sustainability framework was under development until February 2018, with the main goal of creating a process that could facilitate the necessary learning space. The beta version included a guide for experiments comprising a governance proposal for a joint work between LGs and CBIs and an implementation methodology, including the cycles of diagnosis, planning, acting, and evaluation using the grid (similar to the one presented in Table 1). Tutors for supporting pilots' experiments and an intended community of practice were also delivered [79].

According to the sociocratic pattern of consent decision making [80] (p. 29), the framework was considered "good enough for now and safe enough to try".

The framework is now being tested in several communities and results will be shared in future papers. We need to address the critical design principles associated with nurturing these partnerships in practice and study the range of background conditions and institutional arrangements that can influence them. We need to answer questions like how to articulate the CBIs' informal world and the formal world of LGs. Similarly, we want to identify the evolutionary patterns that might emerge from the experiments.

Further research would be needed to analyze more deeply how the eight frameworks fulfil (or not) the preconditions established and to evaluate their potential to be used as a basis for design. Due to time constrains a decision was taken to choose the one that not only seemed promising, but also more accessible for use (the Energy Function was used as a tool in the case study research).

\section{Conclusions}

Our research question is how to promote synergies between local governments and community-based initiatives in their pursuits of (local) sustainability. Our hypothesis is that, by using an appropriate framework and tools, local organizations can effectively create an enhanced combined effect-combining community engagement, reach, and resources-that enables transformations towards sustainability across multiple scales. The research looks for practical knowledge, trying to respond to the urgent need to move from examining transformation to accelerating learning about facilitating it [45]. 
A participatory action research approach was decided, combining efforts from researchers and practitioners. An exploratory case study research led to a set of preconditions for a sustainability framework and a potential candidate was found to be the basis for design. The central element is a grid that allows to map and measure collective transformative action and to identify leverage points. Local governments and community-based initiatives can use this instrument together to represent the existing social capital related to transformation and are challenged to reorganize and expand it, building the stock of change actions and related experiences.

The new sustainability framework is now under experimentation to test our hypothesis about its usefulness and results will be shared in the future.

In synthesis, the scientific contribution of this paper include: (1) An original 'Compass for Collaborative Transformation' as a heuristic device for assessing local transformative collaborations; (2) an innovative method to map the governance imprint and to provide a 'proxy' of transformative efforts; (3) learnings from 71 surveyed cases happening in 16 countries in America and Europe, comparing eight distinctive governance models; (4) preconditions and a basis for a sustainability framework that can be used to boost the transformative reach of cooperation between actors of sustainability.

Author Contributions: Conceptualization, P.M.; formal analysis, P.M.; funding acquisition, N.H.; investigation, P.M., A.H., C.B., J.d.R. and T.B.; methodology, P.M.; project administration, A.H.; supervision, J.M.W. and G.P.-L.; writing —original draft, P.M.; writing—review and editing, A.H., C.B., J.d.R., N.H., T.B., J.M.W. and G.P.-L. All authors have read and agreed to the published version of the manuscript.

Funding: The Municipalities in Transition project is funded by the KR Foundation (Grant ID G-1610-01869). Pedro Macedo and Gil Penha-Lopes wish to acknowledge the Fundação para a Ciência e a Tecnologia, the Portuguese public agency that supports science, technology and innovation (scholarship PD/BD/128170/2016 and contract number IF/00940/2015, respectively).

Acknowledgments: The authors wish to thank the contribution of João Malato in the statistical analyses, all the people involved in data collection and everyone else that supported this research.

Conflicts of Interest: The authors declare no conflict of interest. The funders had no role in the design of the study; in the collection, analyses, or interpretation of data; in the writing of the manuscript, or in the decision to publish the results.

\section{Appendix A}

Table A1. Case studies. More information is available here http://municipalitiesintransition.org/aboutthe-case-studies/case-studies/.

\begin{tabular}{|c|c|c|c|c|}
\hline Name of the Case Study & Country & Location & $\begin{array}{l}\text { Grid } \\
\text { Score }\end{array}$ & Summary \\
\hline $\begin{array}{l}\text { PAED_Plan d'action } \\
\text { énergie durable } \\
\text { (Convenance of the Mayor) }\end{array}$ & Belgium & Ath, Hainaut & 27 & $\begin{array}{l}\text { The Town is building an action plan to decrease } \mathrm{CO}_{2} \\
\text { emissions and to build sustainable energy systems. }\end{array}$ \\
\hline $\begin{array}{l}\text { Halle aux Saveurs-Local } \\
\text { Producers Market }\end{array}$ & Belgium & $\begin{array}{l}\text { Soignies, } \\
\text { Hainaut }\end{array}$ & 18 & $\begin{array}{l}\text { Monthly local producers' market, with focus on artisanal } \\
\text { production, geographical proximity (about } 20 \mathrm{~km} \\
\text { around Soignies) and conviviality. }\end{array}$ \\
\hline $\begin{array}{l}\text { La Ruche qui dit Oui (The } \\
\text { food assembly) }\end{array}$ & Belgium & not defined & 6 & $\begin{array}{l}\text { City connects with farmers for good, fresh and healthy } \\
\text { food and farmers meet the citizens for sharing } \\
\text { knowledge and understanding. }\end{array}$ \\
\hline $\begin{array}{l}\text { Cre@farm + Liège district } \\
\text { territorial development } \\
\text { scheme }\end{array}$ & Belgium & Liège & 41 & $\begin{array}{c}\text { CATL (bottom-up transition initiative) collaborating } \\
\text { with municipalities for access to agricultural land and } \\
\text { other resources. }\end{array}$ \\
\hline Ecobairro São Paulo & Brazil & São Paulo & 34 & $\begin{array}{l}\text { Transition to a local, circular, and participatory } \\
\text { governance in which community members are } \\
\text { encouraged to act responsibly and consciously. }\end{array}$ \\
\hline Bairro Vivo Project & Brazil & $\begin{array}{l}\text { Grajaú, Rio de } \\
\text { Janeiro }\end{array}$ & 36 & $\begin{array}{l}\text { Neighborhood project promoting the awakening of } \\
\text { individual consciousness and the preservation of the } \\
\text { planet and its biodiversity. }\end{array}$ \\
\hline Balloon Latam & Chile & $\begin{array}{l}10 \\
\text { municipalities } \\
\text { in } 3 \text { regions }\end{array}$ & 32 & $\begin{array}{l}\text { Development of local economies in a dynamic of shared } \\
\text { creation between change agents, social entrepreneurs, } \\
\text { municipalities, universities, and other institutions. }\end{array}$ \\
\hline
\end{tabular}


Table A1. Cont.

\begin{tabular}{|c|c|c|c|c|}
\hline Name of the Case Study & Country & Location & $\begin{array}{l}\text { Grid } \\
\text { Score }\end{array}$ & Summary \\
\hline $\begin{array}{l}\text { Challenge in search of an } \\
\text { eco-neighborhood }\end{array}$ & Chile & $\begin{array}{l}\text { Bancaria and } \\
\text { Santa Elena, } \\
\text { Macul, } \\
\text { Santiago }\end{array}$ & 13 & $\begin{array}{c}\text { Eco-neighborhood: In every house a garden, every } \\
\text { neighbor a recycler. }\end{array}$ \\
\hline Transition Rukapillan & Chile & $\begin{array}{c}\text { Kurarrewe, } \\
\text { Panguipulli, } \\
\text { VIllarrica and } \\
\text { Pucón (4 } \\
\text { municipalities) }\end{array}$ & 28 & $\begin{array}{l}\text { Linking and strengthening of sustainable initiatives in } \\
\text { an area that is a world-renowned touristic destination } \\
\text { surrounded by a rich indigenous cultural heritage. }\end{array}$ \\
\hline Santiago en Transición & Chile & $\begin{array}{l}\text { Santiago de } \\
\text { Chile (multiple } \\
\text { Municipalities) }\end{array}$ & 14 & $\begin{array}{l}\text { Unifying the collective genius to remember that we are } \\
\text { paradise on earth. }\end{array}$ \\
\hline $\begin{array}{l}\text { Escuelas de Vida (Schools } \\
\text { of Life) }\end{array}$ & Colombia & Manizales & 37 & $\begin{array}{l}\text { Union of different organizations, foundations, } \\
\text { collectives, and Transition initiatives from Manizales } \\
\text { that join forces around a common purpose. }\end{array}$ \\
\hline Community Living Classes & Colombia & $\begin{array}{l}\text { San Miguel, } \\
\text { San Francisco, } \\
\text { Cundinamarca }\end{array}$ & 13 & $\begin{array}{c}\text { The living classroom is an intervention to strengthen the } \\
\text { community tissues in favor of sustainability and good } \\
\text { living. }\end{array}$ \\
\hline $\begin{array}{l}\text { Nashira a song of love } \\
\text { project for peace }\end{array}$ & Colombia & $\begin{array}{l}\text { Palmira, Bolo } \\
\text { San Isidro. }\end{array}$ & 25 & $\begin{array}{c}\text { Ecovillage - Nashira a sustainable model of peace led by } \\
\text { women for a better quality of life. }\end{array}$ \\
\hline $\begin{array}{l}\text { Promotion of healthy } \\
\text { lifestyle challenges of } \\
\text { formation for the reception } \\
\text { of childhood }\end{array}$ & Colombia & $\begin{array}{l}\text { Arauca, } \\
\text { Palestina, } \\
\text { Caldas. }\end{array}$ & 9 & $\begin{array}{l}\text { Generate new teaching and learning possibilities that } \\
\text { make visible the transformation of healthy lifestyles as a } \\
\text { meaning of education. }\end{array}$ \\
\hline $\begin{array}{c}\text { 7RíosFest of Asociación } \\
\text { 7Ríos }\end{array}$ & Colombia & Cali & 15 & $\begin{array}{l}\text { Making river protection and river basin regeneration of } \\
\text { the seven rivers in Cali fashionable. }\end{array}$ \\
\hline Uelkom & Colombia & $\begin{array}{l}\text { Manizales } \\
\text { Caldas }\end{array}$ & 18 & $\begin{array}{l}\text { Social innovation project towards the transformation of } \\
\text { the reality in vulnerable contexts, based on ethnography } \\
\text { and models of communication. }\end{array}$ \\
\hline $\begin{array}{c}\text { Madre } \\
\text { Kumbra-Ecovillage }\end{array}$ & Colombia & $\begin{array}{l}\text { Manizales, } \\
\text { Caldas }\end{array}$ & 26 & $\begin{array}{l}\text { Madre Kumbra: Territory for meeting, understanding } \\
\text { and sharing with yourself, the other and Nature. }\end{array}$ \\
\hline $\begin{array}{l}\text { Conservation and } \\
\text { sustainable production for } \\
\text { the collective "good } \\
\text { living" }\end{array}$ & Colombia & $\begin{array}{l}\text { San Carlos and } \\
\text { San Rafael, } \\
\text { Antioquia. }\end{array}$ & 36 & $\begin{array}{l}\text { Creating sustainable development in socially and } \\
\text { culturally diverse rural community, around biodiversity } \\
\text { conservation. We seek to unite. }\end{array}$ \\
\hline $\begin{array}{l}\text { Det Fælles Bedste (The } \\
\text { common best) }\end{array}$ & Denmark & Vejle & 21 & $\begin{array}{c}\text { A convergence on solutions for a green sustainable } \\
\text { organic transition. }\end{array}$ \\
\hline The Impact Farm & Denmark & Nørrebro & 30 & $\begin{array}{l}\text { Designing an ambitious urban greenhouse as a Hub for } \\
\text { transition. }\end{array}$ \\
\hline $\begin{array}{c}\text { Transition Town } \\
\text { Silkeborg-The Local } \\
\text { Bicycle Infrastructure Plan }\end{array}$ & Denmark & Silkeborg & 22 & $\begin{array}{l}\text { Collaboration between organizations and municipality } \\
\text { to deliver a local bicycle plan. }\end{array}$ \\
\hline $\begin{array}{l}\text { La filière de la graine à } \\
\text { l'assiette (The process of } \\
\text { the seed to the plate) }\end{array}$ & France & Ungersheim & 14 & $\begin{array}{l}\text { Short circuit for production of organic food, in a wide } \\
\text { context of transition. }\end{array}$ \\
\hline Short supply chains House & France & $\begin{array}{l}\text { Sucy-en-Brie, } \\
\text { Val-de-Marne, } \\
\text { Ile-de-France, } \\
\text { France }\end{array}$ & 14 & $\begin{array}{l}\text { A market hall for local food just born in a collaboration } \\
\text { between municipality and associations. }\end{array}$ \\
\hline Vélo-école & France & $\begin{array}{l}\text { Ménilmontant, } \\
\text { 20ème } \\
\text { arrondissement, } \\
\text { Paris }\end{array}$ & 11 & $\begin{array}{l}\text { Teaching adults to cycle-can be a source of autonomy } \\
\text { and freedom for adults who never learned when they } \\
\text { were younger. }\end{array}$ \\
\hline $\begin{array}{l}\text { Zukunftsstadt Dresden } \\
2030+(\text { future city Dresden } \\
2030+)\end{array}$ & Germany & $\begin{array}{l}\text { Dresden, } \\
\text { Saxony }\end{array}$ & 43 & $\begin{array}{l}\text { Involving the people of Dresden into a strategic } \\
\text { transition-process from visioning via planning to action } \\
\text { and transformation, with scientific monitoring. }\end{array}$ \\
\hline Stadtgärtle & Germany & Esslingen & 13 & $\begin{array}{l}\text { Promoting a public green space to grow vegetables with } \\
\text { the neighborhood. }\end{array}$ \\
\hline Transition Wekerle & Hungary & $\begin{array}{l}\text { Wekerle, } \\
\text { Kispest, } \\
\text { Budapest }\end{array}$ & 25 & $\begin{array}{l}\text { A transitioner trainer was elected as councilor and } \\
\text { promotes sustainability issues. }\end{array}$ \\
\hline Comune di Santorso & Italy & $\begin{array}{l}\text { Santorso } \\
\text { (Vicenza) }\end{array}$ & 18 & $\begin{array}{l}\text { Facilitating the access of the public to technologies like } \\
\text { renewables. It also promotes the integration of refugees, } \\
\text { which is a distinctive feature. }\end{array}$ \\
\hline
\end{tabular}


Table A1. Cont.

\begin{tabular}{|c|c|c|c|c|}
\hline Name of the Case Study & Country & Location & $\begin{array}{l}\text { Grid } \\
\text { Score }\end{array}$ & Summary \\
\hline Energy Function & Italy & $\begin{array}{l}\text { Emilia } \\
\text { Romagna } \\
\text { Region }\end{array}$ & 19 & $\begin{array}{c}\text { Development of a theoretical and operative framework } \\
\text { to address "sustainability and resilience" at local } \\
\text { government level in a systemic way. }\end{array}$ \\
\hline Livorno & Italy & Livorno (City) & 22 & $\begin{array}{l}\text { Emerging new relationship between local government } \\
\text { and citizens searching for new methodologies and tools } \\
\text { to develop and thrive. }\end{array}$ \\
\hline $\begin{array}{l}\text { La Coope-Comunidad de } \\
\text { Intercambio Ecológico y } \\
\text { Solidario }\end{array}$ & Mexico & Querétaro & 24 & $\begin{array}{l}\text { A recent cooperative-community dedicated to the local } \\
\text { food system. }\end{array}$ \\
\hline $\begin{array}{l}\text { Asociacion Projungapeo: } \\
\text { JET (Jungapeo en } \\
\text { Transición) }\end{array}$ & Mexico & $\begin{array}{l}\text { Jungapeo, } \\
\text { Michoacán }\end{array}$ & 40 & $\begin{array}{l}\text { An ongoing community project seeking an integral local } \\
\text { development. }\end{array}$ \\
\hline Bacalar en transición & Mexico & $\begin{array}{c}\text { Bacalar, } \\
\text { Quintana Roo }\end{array}$ & 21 & $\begin{array}{l}\text { Working together to protect the lagoon of Bacalar and } \\
\text { the communities that live here. }\end{array}$ \\
\hline El Itacate & Mexico & $\begin{array}{l}\text { Tepoztlán, } \\
\text { Morelos }\end{array}$ & 19 & $\begin{array}{c}\text { Transition Reconomy project based in Tepoztlan settled } \\
\text { as a think tank lab for helping food gardening, } \\
\text { permaculture and educational projects. }\end{array}$ \\
\hline $\begin{array}{l}\text { Architecture for } \\
\text { sustainability }\end{array}$ & Mexico & $\begin{array}{l}\text { Guadalajara } \\
\text { Jalisco }\end{array}$ & 18 & $\begin{array}{l}\text { Social enterprise oriented to sustainable architecture and } \\
\text { dissemination of tools for resilience. }\end{array}$ \\
\hline $\begin{array}{l}\text { Achterhoekse Groene } \\
\text { Energie Maatschappij } \\
\text { (Achterhoek Green Energy } \\
\text { Cooperative-AGEM) }\end{array}$ & $\begin{array}{l}\text { The } \\
\text { Netherlands }\end{array}$ & $\begin{array}{l}\text { Achterhoek } \\
\text { (region) }\end{array}$ & 29 & $\begin{array}{l}\text { Regional energy cooperative owned and managed by } \\
\text { municipalities. }\end{array}$ \\
\hline $\begin{array}{l}\text { Buurtfonds } \\
\text { Dichters-Rivierenwijk } \\
\text { (Neighbourhood Fund) }\end{array}$ & $\begin{array}{l}\text { The } \\
\text { Netherlands }\end{array}$ & $\begin{array}{l}\text { Dichters and } \\
\text { Rivieren, } \\
\text { Utrecht }\end{array}$ & 8 & $\begin{array}{l}\text { Neighborhood initiative fund aimed at distributing } \\
\text { small grants. }\end{array}$ \\
\hline The Aardehuis project & $\begin{array}{l}\text { The } \\
\text { Netherlands }\end{array}$ & Olst & 35 & $\begin{array}{l}\text { Sustainable living project with } 23 \text { houses and a } \\
\text { community building; municipality, transition initiatives, } \\
\text { and other partners are involved. }\end{array}$ \\
\hline Blue City & $\begin{array}{l}\text { The } \\
\text { Netherlands }\end{array}$ & Rotterdam & 24 & $\begin{array}{c}\text { Breeding ground in Rotterdam for innovative companies } \\
\text { that try to connect their loops together: One company's } \\
\text { output is another company's input. }\end{array}$ \\
\hline $\begin{array}{l}\text { Parceria Local de Telheiras } \\
\text { (Local partnership) }\end{array}$ & Portugal & $\begin{array}{l}\text { Telheiras, } \\
\text { Lumiar, Lisbon }\end{array}$ & 43 & $\begin{array}{l}\text { Neighborhood partnership that resulted from a } \\
\text { transition initiative and a local agenda } 21 \text { promoted by } \\
\text { the municipality. }\end{array}$ \\
\hline Coimbra em Transição & Portugal & Coimbra & 25 & Designing a local hub for transition. \\
\hline Zero Waste Village & Spain & $\begin{array}{l}\text { Orendain, } \\
\text { Gipuzkoa }\end{array}$ & 14 & Project based on waste management/circular economy. \\
\hline $\begin{array}{l}\text { La Garrotxa Territori } \\
\text { Resilient }\end{array}$ & Spain & $\begin{array}{c}\text { Garrotxa }(21 \\
\text { Municipalities) }\end{array}$ & 36 & $\begin{array}{l}\text { Rural region that is home to } 21 \text { municipalities and over } \\
500 \text { local community organizations that work together } \\
\text { towards a sustainable and well-networked society. }\end{array}$ \\
\hline Mares Madrid & Spain & $\begin{array}{l}\text { Province of } \\
\text { Madrid }\end{array}$ & 48 & $\begin{array}{l}\text { Urban transformation by promoting social economy and } \\
\text { collaboration (energy, recycling, food, mobility, and } \\
\text { social care economy). }\end{array}$ \\
\hline $\begin{array}{l}\text { Almócita, semilla en } \\
\text { transición }\end{array}$ & Spain & $\begin{array}{l}\text { Almócita, } \\
\text { Almería, } \\
\text { Andalucía }\end{array}$ & 30 & $\begin{array}{l}\text { Municipality actively participating in the transition } \\
\text { movement, in aspects such as energetic self-sufficiency, } \\
\text { composting, and car-free. }\end{array}$ \\
\hline Iniciativa Rubí Brilla & Spain & $\begin{array}{l}\text { Rubí, Barcelona, } \\
\text { Catalunya }\end{array}$ & 35 & $\begin{array}{l}\text { Local strategy to change the energetic model, promoting } \\
\text { energy saving and energy efficiency in all the sectors of } \\
\text { the city. }\end{array}$ \\
\hline $\begin{array}{l}\text { Descarboniza! Que non é } \\
\text { pouco }\end{array}$ & Spain & $\begin{array}{l}\text { Santiago de } \\
\text { Compostela, } \\
\text { Galicia }\end{array}$ & 19 & $\begin{array}{l}\text { Organize and give support to groups of people who are } \\
\text { willing to "decarbonize" their lifestyles. }\end{array}$ \\
\hline La Colaboradora & Spain & Zaragoza & 33 & $\begin{array}{l}\text { First coworking P2P that promotes a collaborative } \\
\text { economy in the city through a time bank of voluntary } \\
\text { exchange of services and knowledge. }\end{array}$ \\
\hline $\begin{array}{l}\text { Citizen initiative to } \\
\text { improve people's lives in } \\
\text { the municipality }\end{array}$ & Spain & $\begin{array}{l}\text { Quéntar, } \\
\text { Granada }\end{array}$ & 19 & Citizen education for improving community living. \\
\hline $\begin{array}{l}\text { Comunidades en } \\
\text { transición }\end{array}$ & Spain & $\begin{array}{l}\text { Zarzalejo, } \\
\text { Madrid }\end{array}$ & 26 & $\begin{array}{c}\text { Transition Initiatives, CSA, collective space, } \\
\text { transportation, waste management, participatory } \\
\text { budgets. }\end{array}$ \\
\hline
\end{tabular}


Table A1. Cont.

\begin{tabular}{|c|c|c|c|c|}
\hline Name of the Case Study & Country & Location & $\begin{array}{l}\text { Grid } \\
\text { Score }\end{array}$ & Summary \\
\hline $\begin{array}{l}\text { Red Huertos Urbanos } \\
\text { Comunitarios }\end{array}$ & Spain & Madrid & 39 & $\begin{array}{l}\text { Many small gardens will grow small people who will } \\
\text { change the cities. }\end{array}$ \\
\hline Turuta Social currency & Spain & $\begin{array}{l}\text { Vilanova i la } \\
\text { Geltrú }\end{array}$ & 29 & $\begin{array}{l}\text { Promoting collective citizenship projects, including } \\
\text { social currency. }\end{array}$ \\
\hline Sierra Oeste Agroecologica & Spain & $\begin{array}{l}\text { Sierra Oeste de } \\
\text { Madrid (19 } \\
\text { Municipalities) }\end{array}$ & 24 & Regional partnership for agroecological development. \\
\hline $\begin{array}{l}\text { Montequinto (Dos } \\
\text { Hermanas) }\end{array}$ & Spain & Seville & 14 & Permaculture project for local resilience. \\
\hline Jaén en Transición & Spain & Jaén & 37 & $\begin{array}{c}\text { Transition Initiative. The project opts for local initiatives } \\
\text { that are moving towards economic degrowth and good } \\
\text { living. }\end{array}$ \\
\hline $\begin{array}{l}\text { Murcia IT - Innovación y } \\
\text { Tradición }\end{array}$ & Spain & Murcia & 35 & $\begin{array}{l}\text { Participatory Integrated Sustainable Urban } \\
\text { Development strategy. }\end{array}$ \\
\hline $\begin{array}{l}\text { Implementation of the } \\
\text { local digital currency in } \\
\text { the context of intelligent } \\
\text { public spending }\end{array}$ & Spain & $\begin{array}{l}\text { Santa Coloma } \\
\text { de Gramenet, } \\
\text { Barcelona, } \\
\text { Cataluña }\end{array}$ & 37 & $\begin{array}{l}\text { Local currency to promote social and democratic } \\
\text { economy. }\end{array}$ \\
\hline Móstoles en Transición & Spain & Móstoles & 29 & $\begin{array}{l}\text { Transition initiative with the participation of the } \\
\text { municipality; implementation of a new city model that } \\
\text { faces the ecosocial challenges. }\end{array}$ \\
\hline Vilawatt & Spain & $\begin{array}{l}\text { Viladecans, } \\
\text { Barcelona }\end{array}$ & 31 & $\begin{array}{l}\text { Reduction of energy consumption with innovative tools } \\
\text { (local currency). }\end{array}$ \\
\hline Växjö & Sweden & City & 38 & More than 30 years of work on sustainability. \\
\hline $\begin{array}{l}\text { Air quality: An engaging } \\
\text { narrative }\end{array}$ & $\begin{array}{l}\text { United } \\
\text { Kingdom }\end{array}$ & Southampton & 40 & $\begin{array}{l}\text { Concerns about poor local air quality and health have } \\
\text { helped create closer collaboration between local officials, } \\
\text { councilors and groups of residents. }\end{array}$ \\
\hline Caring Town & $\begin{array}{l}\text { United } \\
\text { Kingdom }\end{array}$ & $\begin{array}{l}\text { Market Town of } \\
\text { Totnes (and } \\
\text { surrounding } \\
\text { district), South } \\
\text { Hams, Devon }\end{array}$ & 45 & $\begin{array}{c}\text { Local network of public, voluntary and private } \\
\text { organization coming together to pool resources, skills } \\
\text { and ideas. }\end{array}$ \\
\hline Pollinator Preservation & $\begin{array}{l}\text { United } \\
\text { Kingdom }\end{array}$ & Monmouthshire & 18 & Preserving bees in a transition context. \\
\hline Town Orchards & $\begin{array}{l}\text { United } \\
\text { Kingdom }\end{array}$ & Chepstow & 15 & $\begin{array}{c}\text { The planting of orchards on town council land giving } \\
\text { the community the opportunity to pick sustainably } \\
\text { grown local fruit. }\end{array}$ \\
\hline Walking Bus & $\begin{array}{l}\text { United } \\
\text { Kingdom }\end{array}$ & Chepstow & 17 & $\begin{array}{c}\text { The creation of a walking bus to encourage school } \\
\text { children to walk to school reducing emissions and } \\
\text { creating a healthier lifestyle. }\end{array}$ \\
\hline Climate Protectors & $\begin{array}{l}\text { United } \\
\text { States of } \\
\text { America }\end{array}$ & $\begin{array}{l}\text { Sonoma } \\
\text { County, } \\
\text { California }\end{array}$ & 35 & $\begin{array}{c}\text { The "climate protectors" is a well-structured } \\
\text { collaboration in terms of promoting climate action, both } \\
\text { from public and governments, with seven years of } \\
\text { experience. }\end{array}$ \\
\hline Sanctuary School & $\begin{array}{l}\text { United } \\
\text { States of } \\
\text { America }\end{array}$ & Milwaukee & 10 & $\begin{array}{l}\text { Promoting healing arts with public, special } \\
\text { "underserved communities" and "minorities." Creativity } \\
\text { seems to play a great role. }\end{array}$ \\
\hline $\begin{array}{l}\text { Transition Centre } \\
\text { Emerging Sustainability } \\
\text { Culture }\end{array}$ & $\begin{array}{l}\text { United } \\
\text { States of } \\
\text { America }\end{array}$ & $\begin{array}{l}\text { Centre County, } \\
\text { Pennsylvania }\end{array}$ & 45 & $\begin{array}{l}\text { The project's focus is on promoting a shared vision, } \\
\text { planning, and networking. They give great importance } \\
\text { to economy. }\end{array}$ \\
\hline $\begin{array}{c}\text { Compost pickup in Media } \\
\text { PA }\end{array}$ & $\begin{array}{l}\text { United } \\
\text { States of } \\
\text { America }\end{array}$ & $\begin{array}{c}\text { Media, } \\
\text { Pennsylvania }\end{array}$ & 19 & $\begin{array}{l}\text { Recycling food waste in a transition context and } \\
\text { collaboration with municipality. }\end{array}$ \\
\hline $\begin{array}{l}\text { Transition Streets pilot } \\
\text { project - Des Moines } \\
\text { Climate Action Plan }\end{array}$ & $\begin{array}{l}\text { United } \\
\text { States of } \\
\text { America }\end{array}$ & $\begin{array}{l}\text { Des Moines, } \\
\text { Iowa }\end{array}$ & 30 & Climate Action Plan with a transition context. \\
\hline $\begin{array}{l}\text { Building Community } \\
\text { Resilience through } \\
\text { Grassroots and } \\
\text { Government } \\
\text { Collaborations }\end{array}$ & $\begin{array}{l}\text { United } \\
\text { States of } \\
\text { America }\end{array}$ & $\begin{array}{l}\text { Sonoma, } \\
\text { California }\end{array}$ & 59 & $\begin{array}{l}\text { Decade of successful collaboration between grassroots } \\
\text { and local government that catalyze wide-scale } \\
\text { community action. }\end{array}$ \\
\hline
\end{tabular}




\section{Appendix B}

Table A2. Analyses of eight cases of local collaboration, including governance model, policies, tools, and work in progress.

\begin{tabular}{|c|c|c|c|c|}
\hline & Case History & Governance Model & Policies and Tools & Work in Progress \\
\hline $\begin{array}{c}\text { Daily Acts, } \\
\text { Sonoma, United } \\
\text { States of America }\end{array}$ & $\begin{array}{l}\text { Founded in 2002, Daily Acts (DA) is an educational NGO } \\
\text { whose purpose is to be a catalyst for personal and } \\
\text { community transformation. After running } \\
\text { community-based sustainability education programs for } \\
\text { five years, DA recognized that partnering with LGs was a } \\
\text { critical pathway to build organizational capacity and affect } \\
\text { systemic change. } \\
\text { Meanwhile LGs recognized that DA could offer (1) a unique } \\
\text { ability to engage the community; (2) sustainability expertise; } \\
\text { (3) operating in a cost-effective way. The first contract for a } \\
\text { joint educational program was signed with the city of } \\
\text { Petaluma in } 2007 \text { and others followed. The main barrier } \\
\text { initially was valuing DA's services. }\end{array}$ & $\begin{array}{l}\text { Government partnerships are based on } \\
\text { regular yearly financial contracts to } \\
\text { implement sustainability programs. } \\
\text { DA engages sustainability experts and } \\
\text { a wide range of non-profits, businesses, } \\
\text { government agencies, and other } \\
\text { organizations across the gamut of } \\
\text { sustainability-related issues. DA works } \\
\text { with approximately a dozen different } \\
\text { alliances and networks. } \\
\text { Beyond flattening leadership and } \\
\text { moving it to the edges of the } \\
\text { organization and working in coalitions, } \\
\text { DA is moving in a programmatic } \\
\text { direction that more deeply engages the } \\
\text { leadership of communities. }\end{array}$ & $\begin{array}{l}\text { DA was born out of a permaculture design } \\
\text { approach with the underlying ethical } \\
\text { principles of earth care, people care, and } \\
\text { fair share, and the primary methodology } \\
\text { being to take an integrated and } \\
\text { holistic approach. } \\
\text { DA work with government agencies is a } \\
\text { core strategy to affecting wide-scale } \\
\text { community transformation while building } \\
\text { organizational and movement capacity in } \\
\text { the community resilience field. Some of the } \\
\text { core operating principles are (1) shared } \\
\text { leadership; (2) nurturing non-profit } \\
\text { networks; (3) working with business and } \\
\text { government; (4) doing both program } \\
\text { implementation and advocacy work. }\end{array}$ & $\begin{array}{c}\text { DA promotes 'homegrown programs' } \\
\text { transforming homes and landscapes into } \\
\text { productive, resilient ecosystems--educational } \\
\text { tours expose people to inspiring and practical } \\
\text { examples; workshops help people develop } \\
\text { practical skills; garden installations and } \\
\text { landscape transformations help people work } \\
\text { together to create practical acts of } \\
\text { transformation. } \\
\text { 'Community Resilience Challenge' is an annual } \\
\text { campaign to inspire wide-scale collaborative } \\
\text { action. Activities promoted range from } \\
\text { planting fruit trees to installing greywater and } \\
\text { rainwater catchment systems to committing to } \\
\text { reduce waste, shop local, and hosting } \\
\text { neighborhood potlucks. }\end{array}$ \\
\hline $\begin{array}{l}\text { Ecobairro, São } \\
\text { Paulo, Brazil }\end{array}$ & $\begin{array}{l}\text { Inspiration to Ecobairro came from educational experiences } \\
\text { related to Ecovillages (2004). The initial founders (Lara } \\
\text { Freitas and Paulo Santos) got together with other people } \\
\text { and presented the program in 2005, receiving institutional } \\
\text { support from the City Council and United Nations. } \\
\text { Biggest challenge in the beginning was the lack of public } \\
\text { awareness. The program is now also operating in Salvador } \\
\text { and Feira de Santana. }\end{array}$ & $\begin{array}{l}\text { Ecobairro is an enduring program from } \\
\text { the Roerich Institute of Peace and } \\
\text { Culture of Brazil. In São Paulo it is } \\
\text { hosted by the organization Casa } \\
\text { Urusvati. There is a structure of } \\
\text { coordinators, advisers, and nucleators, } \\
\text { with a systemic approach to leadership. } \\
\text { Decision-making is always in group. }\end{array}$ & $\begin{array}{l}\text { Focus on urban sustainability and } \\
\text { eco-neighborhoods, while connecting } \\
\text { different levels, from personal to planetary. } \\
\text { Project is grounded in the 'mother's } \\
\text { pedagogy,' based on an analogy with } \\
\text { motherhood (fostering values as deep } \\
\text { inclusion, care, intuition, openness, and } \\
\text { flexibility). Use tools like Nonviolent } \\
\text { Communication or Open Space and the } \\
\text { framework of SDG. }\end{array}$ & $\begin{array}{l}\text { Activities include recruitment of volunteers; } \\
\text { active dialogues with local agents and } \\
\text { universities; campaigns, trainings, exhibitions, } \\
\text { and workshops on environmental practices } \\
\text { and topics; networking with the Global } \\
\text { Ecovillage Network and Transition Movement; } \\
\text { collaborating in local public initiatives like } \\
\text { UMAPAZ (Open University for Environment } \\
\text { and Culture of Peace) and Municipal Council } \\
\text { for Environment and Sustainable } \\
\text { Development. }\end{array}$ \\
\hline $\begin{array}{l}\text { Energy Function, } \\
\text { Emilia Romagna, } \\
\text { Italy }\end{array}$ & $\begin{array}{l}\text { In } 2008 \text { "Monteveglio Città di Transizione" was the first } \\
\text { Transition Initiative in Italy and started its activity with a } \\
\text { quite visible, official and unusual strategic partnership with } \\
\text { the Municipality. Together they led action on the Covenant } \\
\text { of Mayors and succeeded in involving the whole 'Unione di } \\
\text { Comuni' (6 municipalities). This was the basis for a } \\
\text { partnership with the regional branch of ANCI (National } \\
\text { Association of Municipalities), in 2009, aimed at replicating } \\
\text { this example and create support tools. CURSA (University } \\
\text { Consortium for Socioeconomic and Environmental } \\
\text { Research) joined the effort on the behalf of the national } \\
\text { Environmental Ministry. } \\
\text { After a few years of experiments was evident the need of a } \\
\text { general framework to make easier the day by day } \\
\text { challenges posed by the complexity of the different contexts. }\end{array}$ & $\begin{array}{l}\text { It is believed that energy issues (and } \\
\text { the necessary transition to a low-carbon } \\
\text { economy) brings new challenges to } \\
\text { local governance and should be } \\
\text { included as a new municipalities' } \\
\text { function (changing legislation). } \\
\text { The Energy Function (EF) should be a } \\
\text { local policy transversal to all existent } \\
\text { policies; focused on facilitation and } \\
\text { support of families and businesses; } \\
\text { grounded in multi-level governance; } \\
\text { strictly dependent on the peculiarities } \\
\text { of the territory (natural and social } \\
\text { capital); urgent while having a } \\
\text { medium-long term perspective. }\end{array}$ & $\begin{array}{l}\text { The principle for designing the EF were: } \\
\text { having a general, systemic framework easy } \\
\text { enough to be understood with a simple } \\
\text { learning curve and having a way to } \\
\text { organize all the available tools, } \\
\text { methodologies and needed information for } \\
\text { those trying to work in the field. } \\
\text { In spite of the name, the actual model for } \\
\text { the EF can hold much more than "energy } \\
\text { issues" being a systemic tool strongly } \\
\text { inspired by the Transition work, system } \\
\text { thinking, and various theories of change } \\
\text { approaches. It has a stochastic design. }\end{array}$ & $\begin{array}{l}\text { The Energy Function approach is based on a } \\
\text { relationship grid that holds the "scenario" and } \\
\text { an intended pattern language database that } \\
\text { contains tools and needed information. All is } \\
\text { designed to be practical and grounded on } \\
\text { reality but without simplifying the complex } \\
\text { environment and set of conditions and } \\
\text { relationships real life presents. } \\
\text { The EF was indicated as a necessary tool on the } \\
\text { Regional Energy Strategy of Emilia Romagna } \\
\text { but kept underdeveloped. }\end{array}$ \\
\hline
\end{tabular}


Table A2. Cont.

\begin{tabular}{|c|c|c|c|c|}
\hline & Case History & Governance Model & Policies and Tools & Work in Progress \\
\hline $\begin{array}{c}\text { Future City } \\
\text { Dresden 2030+, } \\
\text { Dresden, } \\
\text { Germany }\end{array}$ & $\begin{array}{l}\text { In 2015, the Federal Ministry of Education and Research } \\
\text { (BMBF) launched the Future City for Sustainable } \\
\text { Development competition. Three phases were considered: } \\
\text { (1) Development of a common vision; (2) planning; (3) } \\
\text { implementation. Dresden's government decided to apply in } \\
2015 \text { and is one of the seven finalists going for phase } 3 \text { in } \\
2019 \text {, receiving around one million euros for that purpose. }\end{array}$ & $\begin{array}{l}\text { The process is driven by the } \\
\text { municipality through a project manager } \\
\text { who formed a 'Future City team.' First } \\
\text { project partners were two scientific } \\
\text { bodies, the Leibniz Institute of } \\
\text { Ecological Urban and Regional } \\
\text { Development and the Knowledge } \\
\text { Architecture at the University of } \\
\text { Dresden (with experience in designing } \\
\text { processes for working with people). In } \\
\text { phase } 2 \text { other partners joined (e.g., } \\
\text { public transport company and energy } \\
\text { provider) and a group was formed. } \\
\text { Involvement was restricted to some } \\
\text { meetings and a conference. Stronger } \\
\text { collaborations are expected in phase } 3, \\
\text { with joint implementation of projects. } \\
\text { People from civil society were involved } \\
\text { and there is a sense of excitement with } \\
\text { the possibilities to collaborate. }\end{array}$ & $\begin{array}{l}\text { The initiative follows the inspiration from } \\
\text { the Transition Movement, empowering } \\
\text { people to act at their own places, creating } \\
\text { rooms where they can meet ("people own } \\
\text { the city, and they should be the ones } \\
\text { developing it"). In this way, it is considered } \\
\text { a pioneering project in the government. } \\
\text { Discussion rooms have been streamlined to } \\
\text { support people in the process of creating } \\
\text { projects. For example, identifying } \\
\text { objectives, problems to solve, useful } \\
\text { personal experiences and skills, evaluation } \\
\text { criteria, etc. }\end{array}$ & $\begin{array}{l}\text { The initiative concentrates on the process as } \\
\text { designed by BMBF, following what was } \\
\text { included in the application. } \\
\text { In this phase (2) efforts are directed to } \\
\text { codesigning projects. } \\
\text { Although this planning phase is considered too } \\
\text { abstract by some participants, it is believed } \\
\text { that it is affecting how people face } \\
\text { sustainability issues and their own role in the } \\
\text { city. Stronger connections are believed to be } \\
\text { the greatest outcome at this stage. } \\
\text { A catalogue was prepared with all the ideas } \\
\text { relating to education, campus and citizen } \\
\text { knowledge; neighborhood; energy; sustainable } \\
\text { economy and business model; mobility; urban } \\
\text { space; citizen participation; culture and capital } \\
\text { of culture. }\end{array}$ \\
\hline $\begin{array}{c}\text { Jungapeo en } \\
\text { Transición, } \\
\text { Jungapeo, } \\
\text { Mexico }\end{array}$ & $\begin{array}{l}\text { The NGO 'Pro Desarrollo Integral del Municipio de } \\
\text { Jungapeo' was created in } 2015 \text { (grassroots' activities started } \\
\text { in 2005), focused in local, integral development. In } 2016 \text { the } \\
\text { local mayor challenged the NGO to transform Jungapeo } \\
\text { into the first official Transition town in México, which led to } \\
\text { a signed agreement. } \\
\text { Barriers are mistrusted based on previous bad experiences; } \\
\text { apathy by the population; short exercise of power of the } \\
\text { municipal authorities; lack of continuity due to overwork. }\end{array}$ & $\begin{array}{l}\text { Jungapeo en Transición (JET) is } \\
\text { managed by a full-time staff dependent } \\
\text { on the CBI. It is grounded in a matrix } \\
\text { organization with three axes (social, } \\
\text { agriculture, and tourism) and five } \\
\text { components that interact with the axes } \\
\text { (ecology, culture, health, education, and } \\
\text { sports). Collaboration with } \\
\text { municipality is supported by regular } \\
\text { briefings and by inviting members of } \\
\text { the municipality to workshops and } \\
\text { activities. } \\
\text { Local agents are involved, also through } \\
\text { focal groups (children, students, } \\
\text { business, teachers, elders). }\end{array}$ & $\begin{array}{l}\text { Inspiration comes mainly from the } \\
\text { Transition Movement. It intends to } \\
\text { "eradicate the mentality of assistencialism } \\
\text { and dependency" and empower the } \\
\text { community to identify their needs and help } \\
\text { to resolve them. } \\
\text { Collaboration between LGs and CBIs is } \\
\text { expected to grow based on trust and } \\
\text { confidence arriving from joint successful } \\
\text { activities-small initial steps with big } \\
\text { visibility. } \\
\text { Tools like sociocracy, coaching, and } \\
\text { Robert's Rules of Order are used to foster } \\
\text { inclusion and participation. }\end{array}$ & $\begin{array}{c}\text { Organized activities range from cleaning rivers } \\
\text { to competitions to honoring the dead } \\
\text { (embedded in Mexican culture), local markets } \\
\text { to dry toilets. } \\
\text { An educational approach is the focus, } \\
\text { including workshops for elders, youth and } \\
\text { other groups. } \\
\text { Regardless of the several results that have } \\
\text { emanated from own projects, they have been } \\
\text { able to observe recent "outbreaks" of } \\
\text { spontaneous and orderly teamwork among the } \\
\text { local population, "as if the Transition Effect } \\
\text { were contagious." } \\
\text { Monitoring includes regular and extensive } \\
\text { surveys to partners, beneficiaries and public. }\end{array}$ \\
\hline
\end{tabular}


Table A2. Cont.

\begin{tabular}{|c|c|c|c|c|}
\hline & Case History & Governance Model & Policies and Tools & Work in Progress \\
\hline $\begin{array}{l}\text { MARES, Madrid, } \\
\text { Spain }\end{array}$ & $\begin{array}{l}\text { The economic crisis of } 2008 \text { increased unemployment and } \\
\text { urban social-spatial segregation. Dinamia (social consulting) } \\
\text { joined the municipality, Tangente and Vivero de Iniciativas } \\
\text { Ciudadanas (two collaborative platforms) with the idea of } \\
\text { supporting existent CBIs related to social and solidarity } \\
\text { economy. Other partners joined the initiative. }\end{array}$ & $\begin{array}{l}\text { MARES is a partnership centralised in } \\
\text { the Council. Several partners } \\
\text { participate in the executive, economic } \\
\text { and finance committee (with voting } \\
\text { rights) and steering groups (led by } \\
\text { different partners). Control processes } \\
\text { were defined, such as management } \\
\text { plan, quality plan, risk assessment plan, } \\
\text { evaluation system and monitoring, } \\
\text { handbook of internal communication } \\
\text { and decision making. }\end{array}$ & $\begin{array}{l}\text { The focus is on urban economic resilience. } \\
\text { It intends to strengthen the emerging } \\
\text { opportunities in strategic sectors (transport, } \\
\text { food, waste, energy, and care, MARES in } \\
\text { Spanish). It seeks for cooperation among } \\
\text { local actors, social innovation and the } \\
\text { active productive involvement of citizens. } \\
\text { The base is to "put the people before the } \\
\text { profit." Use tools like the co-design for the } \\
\text { reuse of disused buildings and public } \\
\text { spaces; mapping citizens' competencies; } \\
\text { analysis of care needs and proposal for } \\
\text { value chain; learning communities. }\end{array}$ & $\begin{array}{l}\text { Initiatives of collective self-employment by } \\
\text { means of increase awareness, training and } \\
\text { support to citizen groups. The biggest } \\
\text { challenge is the generation of real participatory } \\
\text { public policies in the functional and social } \\
\text { fields. There are expects outcomes like a } \\
\text { change of transport to low emission models, } \\
\text { implementation of renewable energies and } \\
\text { energy efficiency, improved care for older } \\
\text { people and for the infancy, consume of local } \\
\text { products and agroecologic food, hopefully } \\
\text { generating employment. }\end{array}$ \\
\hline $\begin{array}{l}\text { Rubí Brilla, Rubí, } \\
\text { Spain }\end{array}$ & $\begin{array}{l}\text { In } 2008 \text { the Rubí Council joined the Covenant of Mayors, } \\
\text { within the European initiative to reduce carbon emissions. } \\
\text { A Plan of Action for Sustainable Energies was prepared } \\
\text { externally, with the support of Barcelona Council. The Rubí } \\
\text { Brilla initiative started in } 2011 \text {. } \\
\text { Angel Ruiz, working for the municipality and private } \\
\text { entrepreneur, played a key role by bringing expertise and a } \\
\text { business perspective. }\end{array}$ & $\begin{array}{l}\text { Rubí Brilla is a service provided by the } \\
\text { municipality and managed by a } \\
\text { working group of eight internal } \\
\text { technicians. Energy experts have been } \\
\text { hired in } 2013 \text { and several collaborations } \\
\text { are established with external entities. } \\
\text { A specific partnership is built with } \\
\text { schools and other public organizations, } \\
\text { where decisions are taken } \\
\text { collectively-in this context savings } \\
\text { from investment in energy efficiency } \\
\text { are locally reinvested ( } 50 \% \text { in new } \\
\text { measures for energy saving, leading to } \\
\text { a positive feedback loop). }\end{array}$ & $\begin{array}{l}\text { The initiative uses the economic factor as } \\
\text { the leading motivational factor and } \\
\text { prioritizes economic tools commonly used } \\
\text { in the business sector. Using the 'pareto } \\
\text { principle' they focused on energy efficiency } \\
\text { in public buildings. Substantial emissions } \\
\text { and cost reduction were achieved so } \\
\text { 'profits' were reinvested in new actions } \\
\text { (energy efficiency and renewable energy). } \\
\text { The clear cost-cutting is used as an } \\
\text { argument to convince private partners. }\end{array}$ & $\begin{array}{l}\text { A major part of the work done relates to the } \\
\text { private sector (industry accounts for } 40 \% \text { of } \\
\text { emissions). This is mostly done by promoting } \\
\text { technical meetings with the biggest energy } \\
\text { users, were learnings are shared and support is } \\
\text { provided. This includes collaborations with } \\
\text { the Polytechnic University of Catalunya. } \\
\text { Other activities include providing monitoring } \\
\text { apps to families, energy centers at } \\
\text { neighborhood level, and buying } \\
\text { electric vehicles. } \\
\text { Data monitoring is a key activity, including } \\
\text { real time checking of consumption and } \\
\text { efficiency indicators. Citizens are provided } \\
\text { with information on energy costs in public } \\
\text { buildings and street lighting. }\end{array}$ \\
\hline Växjö, Sweden & $\begin{array}{l}\text { The municipality saw a need to restore the local lakes in } \\
1969 \text { and the environmental focus has continued since then. } \\
\text { In } 1993 \text {, LG approved a local environmental policy and in } \\
1996 \text { decided to become a fossil fuel-free municipality. In } \\
\text { 1999, a Local Agenda } 21 \text { strategy for Sustainable Växjö was } \\
\text { adopted. In 2006, the LG's Environmental Program was } \\
\text { agreed (updated in } 2010 \text { and 2014). } \\
\text { Several participatory efforts (polls, meetings ... ) have been } \\
\text { tried but the results were unsatisfactory. }\end{array}$ & $\begin{array}{l}\text { The development has been driven by } \\
\text { municipal departments and } \\
\text { municipally-owned corporations. Since } \\
\text { May } 2016 \text { there is a sustainability group } \\
\text { which is part of the development unit } \\
\text { of the municipal management. The } \\
\text { group has two politicians assigned to it } \\
\text { and formulates the Environmental } \\
\text { Program. It is up to each operation unit } \\
\text { to break this down into actionable, } \\
\text { budgeted steps with measures related } \\
\text { to the goals. }\end{array}$ & $\begin{array}{l}\text { The main principle is to promote a strong } \\
\text { political leadership with bold decisions. } \\
\text { The basic approach, since } 1969 \text {, has been a } \\
\text { sequence of political decision > steering } \\
\text { documents }>\text { goals }>\text { municipal } \\
\text { boards/corporations plans > budgets > } \\
\text { follow up > publication in annual report } \\
\text { with goal scorecards. } \\
\text { To assure continuity three main factors are } \\
\text { considered: (1) Consensus among parties; } \\
\text { (2) direct involvement of politicians; (3) } \\
\text { strong management structure in place. } \\
\text { Work is underway to align the program } \\
\text { with the SDGs (ready 2019). }\end{array}$ & $\begin{array}{l}\text { The Environmental Program's measurable } \\
\text { goals are planned and monitored through } \\
\text { Växjö municipality's management system. } \\
\text { Each municipal steering board and company } \\
\text { are responsible for fulfillment of the goals as } \\
\text { well as to deliver statistics. The annual report } \\
\text { is publicly available. } \\
\text { Multiple outcomes are visible, like better air } \\
\text { and water quality, green spaces, or } \\
\text { sophisticated waste sorting. } \\
\text { There is a feeling of pride in being at the } \\
\text { forefront of environmental development. }\end{array}$ \\
\hline
\end{tabular}




\section{References}

1. Steffen, W.; Broadgate, W.; Deutsch, L.; Gaffney, O.; Ludwig, C. The trajectory of the Anthropocene: The Great Acceleration. Anthr. Rev. 2015, 2, 81-98. [CrossRef]

2. Göpel, M. The Great Mindshift; The Anthropocene: Politik-Economics-Society-Science; Springer International Publishing: Cham, Switzerland, 2016; Volume 2, ISBN 978-3-319-43765-1.

3. Vangen, S. Developing Practice-Oriented Theory on Collaboration: A Paradox Lens. Public Adm. Rev. 2017, 77, 263-272. [CrossRef]

4. Patel, H.; Pettitt, M.; Wilson, J.R. Factors of collaborative working: A framework for a collaboration model. Appl. Ergon. 2012, 43, 1-26. [CrossRef] [PubMed]

5. IPCC. Climate Change 2014: Impacts, Adaptation, and Vulnerability. Part A: Global and Sectoral Aspects. Contribution of Working Group II to the Fifth Assessment Report of the Intergovernmental Panel on Climate Change; Field, C.B., Barros, V.R., Dokken, D.J., Mach, K.J., Mastrandrea, M.D., Bilir, T.E., Chatterjee, M., Ebi, K.L., Estrada, Y.O., Genova, R.C., et al., Eds.; Cambridge University Press: Cambridge, UK; New York, NY, USA, 2014; ISBN 9781107415379.

6. Loorbach, D.; Frantzeskaki, N.; Avelino, F. Sustainability Transitions Research: Transforming Science and Practice for Societal Change. Annu. Rev. Environ. Resour. 2017, 42, 599-626. [CrossRef]

7. Markard, J.; Raven, R.; Truffer, B. Sustainability transitions: An emerging field of research and its prospects. Res. Policy 2012, 41, 955-967. [CrossRef]

8. EEA. Perspectives on Transitions to Sustainability; European Environment Agency: Luxembourg, 2018; ISBN 978-92-9213-939-1.

9. Patterson, J.; Schulz, K.; Vervoort, J.; van der Hel, S.; Widerberg, O.; Adler, C.; Hurlbert, M.; Anderton, K.; Sethi, M.; Barau, A. Exploring the Governance and Politics of Transformations towards Sustainability; Elsevier B.V.: Amsterdam, The Netherlands, 2017; Volume 24, pp. 1-16.

10. Abson, D.J.; Fischer, J.; Leventon, J.; Newig, J.; Schomerus, T.; Vilsmaier, U.; von Wehrden, H.; Abernethy, P.; Ives, C.D.; Jager, N.W.; et al. Leverage points for sustainability transformation. Ambio 2017, 46, 30-39. [CrossRef]

11. Miller, T.R.; Wiek, A.; Sarewitz, D.; Robinson, J.; Olsson, L.; Kriebel, D.; Loorbach, D. The future of sustainability science: A solutions-oriented research agenda. Sustain. Sci. 2014, 9, 239-246. [CrossRef]

12. Fazey, I.; Moug, P.; Allen, S.; Beckmann, K.; Blackwood, D.; Bonaventura, M.; Burnett, K.; Danson, M.; Falconer, R.; Gagnon, A.S.; et al. Transformation in a changing climate: A research agenda. Clim. Dev. 2018, 10, 197-217. [CrossRef]

13. Frantzeskaki, N.; Dumitru, A.; Anguelovski, I.; Avelino, F.; Bach, M.; Best, B.; Binder, C.; Barnes, J.; Carrus, G.; Egermann, M.; et al. Elucidating the changing roles of civil society in urban sustainability transitions. Curr. Opin. Environ. Sustain. 2017, 22, 41-50. [CrossRef]

14. Campos, I.S.; Alves, F.M.; Dinis, J.; Truninger, M.; Vizinho, A.; Penha-Lopes, G. Climate adaptation, transitions, and socially innovative action-research approaches. Ecol. Soc. 2016, 21, 13. [CrossRef]

15. Kropotkin, P. Mutual Aid: A Factor of Evolution; Courier Corporation: North Chelmsford, MA, USA, 2012.

16. Curry, O.S.; Mullins, D.A.; Whitehouse, H. Is It Good to Cooperate? Testing the Theory of Morality-as-Cooperation in 60 Societies. Curr. Anthropol. 2019, 60, 47-69. [CrossRef]

17. Kohn, A. No Contest: The Case against Competition; Houghton Mifflin Harcourt: New York, NY, USA, 1992; ISBN 0395631254.

18. Lozano, R. Collaboration as a pathway for sustainability. Sustain. Dev. 2007, 15, 370-381. [CrossRef]

19. Niesten, E.; Jolink, A.; Lopes de Sousa Jabbour, A.B.; Chappin, M.; Lozano, R. Sustainable collaboration: The impact of governance and institutions on sustainable performance. J. Clean. Prod. 2017, 155, 1-6. [CrossRef]

20. Bryson, J.M.; Crosby, B.C.; Stone, M.M. Designing and Implementing Cross-Sector Collaborations: Needed and Challenging. Public Adm. Rev. 2015, 75, 647-663. [CrossRef]

21. Weible, C.M.; Sabatier, P.A. Coalitions, Science, and Belief Change: Comparing Adversarial and Collaborative Policy Subsystems. Policy Stud. J. 2009, 37, 195-212. [CrossRef]

22. Frantzeskaki, N.; Wittmayer, J.; Loorbach, D. The role of partnerships in "realising" urban sustainability in Rotterdam's City Ports Area, the Netherlands. J. Clean. Prod. 2014, 65, 406-417. [CrossRef]

23. Forsyth, T. Panacea or paradox? Cross-sector partnerships, climate change, and development. Wiley Interdiscip. Rev. Clim. Chang. 2010, 1, 683-696. [CrossRef] 
24. Westman, L.; Broto, V.C. Climate governance through partnerships: A study of 150 urban initiatives in China. Glob. Environ. Chang. 2018, 50, 212-221. [CrossRef]

25. Van Huijstee, M.M.; Francken, M.; Leroy, P. Partnerships for sustainable development: A review of current literature. Environ. Sci. 2007, 4, 75-89. [CrossRef]

26. Vergragt, P.J.; Quist, J. Backcasting for sustainability: Introduction to the special issue. Technol. Forecast. Soc. Chang. 2011, 78, 747-755. [CrossRef]

27. Wiek, A.; Iwaniec, D. Quality criteria for visions and visioning in sustainability science. Sustain. Sci. 2014, 9, 497-512. [CrossRef]

28. Eisenhauer, D.C. Pathways to Climate Change Adaptation: Making Climate Change Action Political. Geogr. Compass 2016, 10, 207-221. [CrossRef]

29. Leach, M.; Rockström, J.; Raskin, P.; Scoones, I.; Stirling, A.C.; Smith, A.; Thompson, J.; Millstone, E.; Ely, A.; Arond, E.; et al. Transforming Innovation for Sustainability. Ecol. Soc. 2012, 17, 11. [CrossRef]

30. Loorbach, D. Transition Management for Sustainable Development: A Prescriptive, Complexity-Based Governance Framework. Governance 2010, 23, 161-183. [CrossRef]

31. Loorbach, D. Transition Management, New Mode of Governance for Sustainable Development; International Books: Utrecht, The Netherlands, 2007; ISBN 978-90-5727-057-4.

32. Loorbach, D.; Rotmans, J. The practice of transition management: Examples and lessons from four distinct cases. Futures 2010, 42, 237-246. [CrossRef]

33. Nevens, F.; Frantzeskaki, N.; Gorissen, L.; Loorbach, D. Urban Transition Labs: Co-creating transformative action for sustainable cities. J. Clean. Prod. 2013, 50, 111-122. [CrossRef]

34. Rydin, Y.; Pennington, M. Public Participation and Local Environmental Planning: The collective action problem and the potential of social capital. Local Environ. 2000, 5, 153-169. [CrossRef]

35. Hassink, J.; Salverda, I.; Vaandrager, L.; van Dam, R.; Wentink, C. Relationships between green urban citizens' initiatives and local governments. Cogent Soc. Sci. 2016, 2, 1-18. [CrossRef]

36. TESS. Final Publishable Summary Report; European Research Project TESS (Towards European Societal Sustainability): Potsdam, Germany, 2017.

37. BASE. Key Policy Issues in Implementing and Evaluating the EU Adaptation Strategy; Research Project BASE Bottom-Up Climate Adaptation Strategies Towards a Sustainable Europe: Aarhus, Denmark, 2016.

38. Henfrey, T.; Penha-Lopes, G. Policy and community-led action on sustainability and climate change: Paradox and possibility in the interstices. Environ. Innov. Soc. Transitions 2018, 29, 52-54. [CrossRef]

39. Revell, P.; Henderson, C. Operationalising a framework for understanding community resilience in Europe. Reg. Environ. Chang. 2019, 19, 967-979. [CrossRef]

40. Bovaird, T. Beyond Engagement and Participation: User and Community Coproduction of Public Services. Public Adm. Rev. 2007, 67, 846-860. [CrossRef]

41. Ostrom, E. Crossing the great divide: Coproduction, synergy, and development. World Dev. 1996, 24, 1073-1087. [CrossRef]

42. Avelino, F.; Bosman, R.; Frantzeskaki, N.; Akerboom, S.; Boontje, P.; Hoffman, J.; Paradies, G.; Pel, B.; Scholten, D.; Wittmayer, J. The (Self-)Governance of Community Energy: Challenges \& Prospects; DRIFT: Rotterdam, The Netherlands, 2014.

43. Chapin, F.S.; Carpenter, S.R.; Kofinas, G.P.; Folke, C.; Abel, N.; Clark, W.C.; Olsson, P.; Smith, D.M.S.; Walker, B.; Young, O.R.; et al. Ecosystem stewardship: Sustainability strategies for a rapidly changing planet. Trends Ecol. Evol. 2010, 25, 241-249. [CrossRef] [PubMed]

44. Amundsen, H.; Hovelsrud, G.K.; Aall, C.; Karlsson, M.; Westskog, H. Local governments as drivers for societal transformation: Towards the $1.5^{\circ} \mathrm{C}$ ambition. Curr. Opin. Environ. Sustain. 2018, 31, 23-29. [CrossRef]

45. Fazey, I.; Carmen, E.; Chapin, F.; Ross, H.; Rao-Williams, J.; Lyon, C.; Connon, I.; Searle, B.; Knox, K. Community resilience for a $1.5^{\circ} \mathrm{C}$ world. Curr. Opin. Environ. Sustain. 2018, 31, 30-40. [CrossRef]

46. Bendell, J. Deep Adaptation: A Map for Navigating Climate Tragedy. IFLAS Occas. Pap. 2018, 2, 1-31.

47. Avelino, F.; Wittmayer, J.M.; Pel, B.; Weaver, P.; Dumitru, A.; Haxeltine, A.; Kemp, R.; Jørgensen, M.S.; Bauler, T.; Ruijsink, S.; et al. Transformative social innovation and (dis)empowerment. Technol. Forecast. Soc. Chang. 2019, 145, 195-206. [CrossRef]

48. Beers, P.J.; Sol, J.; Wals, A. Social Learning in a Multi-Actor Innovation Context. In Proceedings of the 9th European IFSA Symposium, Vienna, Austria, 4-7 July 2010; pp. 144-153. 
49. Shove, E.; Walker, G. Governing transitions in the sustainability of everyday life. Res. Policy 2010, 39, 471-476. [CrossRef]

50. Markard, J.; Truffer, B. Technological innovation systems and the multi-level perspective: Towards an integrated framework. Res. Policy 2008, 37, 596-615. [CrossRef]

51. Hendriks, C.M. Policy design without democracy? Making democratic sense of transition management. Policy Sci. 2009, 42, 341-368. [CrossRef]

52. Ruijsink, S.; Olivotto, V.; Taanman, M.; Cozan, S.; Weaver, P.; Kemp, R.; Wittmayer, J. Social Innovation Evaluation tool: Critical Turning Points and Narratives of Change; TRANSIT: Rotterdam, The Netherlands, 2017.

53. Fuenfschilling, L.; Truffer, B. The structuration of socio-technical regimes-Conceptual foundations from institutional theory. Res. Policy 2014, 43, 772-791. [CrossRef]

54. Geels, F.W.; Verhees, B. Cultural legitimacy and framing struggles in innovation journeys: A cultural-performative perspective and a case study of Dutch nuclear energy (1945-1986). Technol. Forecast. Soc. Chang. 2011, 78, 910-930. [CrossRef]

55. Tosun, J.; Schoenefeld, J.J. Collective climate action and networked climate governance. Wiley Interdiscip. Rev. Clim. Chang. 2017, 8, e440. [CrossRef]

56. Geels, F.W. Ontologies, socio-technical transitions (to sustainability), and the multi-level perspective. Res. Policy 2010, 39, 495-510. [CrossRef]

57. Bogers, M.; Chesbrough, H.; Moedas, C. Open Innovation: Research, Practices, and Policies. Calif. Manage. Rev. 2018, 60, 5-16. [CrossRef]

58. Stringer, E.T. Action Research; Sage Ppublications: Thousand Oaks, CA, USA, 2013; ISBN 978-1-4833-0183-9.

59. Adams, M.; Alexander, C.; Beale, N.; Brightbill, N.; Cahill, C.; Cameron, J.; Chatterton, P.; Cieri, M.; Coe, C.; Dolan, C.; et al. Participatory Action Research Approaches and Methods: Connecting People, Participation and Place; Kindon, S., Pain, R., Kesby, M., Eds.; Routledge: New York, NY, USA, 2007; ISBN 0-203-93367-2.

60. Wittmayer, J.M.; Schäpke, N. Action, research and participation: Roles of researchers in sustainability transitions. Sustain. Sci. 2014, 9, 483-496. [CrossRef]

61. Grossmann, M.; Creamer, E. Assessing diversity and inclusivity within the Transition movement: An urban case study. Environ Polit. 2017, 26, 161-182. [CrossRef]

62. Fernandes-Jesus, M.; Carvalho, A.; Fernandes, L.; Bento, S. Community engagement in the Transition movement: Views and practices in Portuguese initiatives. Local Environ. 2017, 22, 1546-1562. [CrossRef]

63. Penha-Lopes, G.; Henfrey, T. Reshaping the Future: How Local Communities Are Catalysing Social, Economic and Ecological Transformation in Europe. The First Status Report on Community-led Action on Sustainability and Climate Change in Europe; ECOLISE: Brussels, Belgium, 2019; ISBN 978-2-9602393-0-0.

64. Biddau, F.; Armenti, A.; Cottone, P. Socio-psychological aspects of grassroots participation in the Transition Movement: An Italian case study. J. Soc. Polit. Psychol. 2016, 4, 142-165. [CrossRef]

65. Longhurst, N.; Pataki, G. WP4 CASE STUDY Report: The Transition Movement; TRANSIT: Rotterdam, The Netherlands, 2015.

66. Smith, A. The Transition Town Network: A Review of Current Evolutions and Renaissance. Soc. Mov. Stud. 2011, 10, 99-105. [CrossRef]

67. Feola, G.; Nunes, R. Success and failure of grassroots innovations for addressing climate change: The case of the Transition Movement. Glob. Environ. Chang. 2014, 24, 232-250. [CrossRef]

68. Rossi, A.; Pinca, G.; Cavalletti, A.; Bartolomei, M.; Bottone, C. La Funzione Energia nei Comuni e nelle Unioni. In Qualità Dell'ambiente Urbano-X Rapporto-Focus su Le Città e la Sfida dei Cambiamenti Climatici; ISPRA: Roma, Italia, 2014; ISBN 978-88-448-0686-6.

69. Aguiar, F.C.; Bentz, J.; Silva, J.M.N.; Fonseca, A.L.; Swart, R.; Santos, F.D.; Penha-Lopes, G. Adaptation to climate change at local level in Europe: An overview. Environ. Sci. Policy 2018, 86, 38-63. [CrossRef]

70. Seyfang, G.; Park, J.J.; Smith, A. A thousand flowers blooming? An examination of community energy in the UK. Energy Policy 2013, 61, 977-989. [CrossRef]

71. Rendon, O.; Gebhardt, O.; Branth Pedersen, A.; Breil, M.; Campos, I.; Chiabai, A.; Den Uyl, R.M.; Foudi, S.; Garrote, L.; Harmáčková, Z.; et al. Implementation of Climate Change Adaptation: Barriers and Opportunities to Adaptation in Case Studies; BASE: Leeds, UK, 2016.

72. Schoon, M.; Cox, M. Collaboration, Adaptation, and Scaling: Perspectives on Environmental Governance for Sustainability. Sustainability 2018, 10, 679. [CrossRef] 
73. EEA. Urban Adaptation to Climate Change in Europe 2016-Transforming Cities in a Changing Climate; European Environment Agency: Luxembourg, 2016.

74. Turnheim, B.; Berkhout, F.; Geels, F.; Hof, A.; McMeekin, A.; Nykvist, B.; van Vuuren, D. Evaluating sustainability transitions pathways: Bridging analytical approaches to address governance challenges. Glob. Environ. Chang. 2015, 35, 239-253. [CrossRef]

75. Jørgensen, U. Mapping and navigating transitions-The multi-level perspective compared with arenas of development. Res. Policy 2012, 41, 996-1010. [CrossRef]

76. Cunsolo, A.; Ellis, N.R. Ecological grief as a mental health response to climate change-related loss. Nat. Clim. Chang. 2018, 8, 275-281. [CrossRef]

77. Lertzman, R. Environmental Melancholia-Psychoanalytic Dimensions of Engagement; Routledge: London, UK, 2015; ISBN 9781315851853.

78. Macy, J.; Brown, M.Y. Coming Back to Life: The Updated Guide to the Work that Reconnects; New Society Publishers: Gabriola Island, BC, Canada, 2014; ISBN 978-1-55092-580-7.

79. MiT. The MiT Framework for the Pilots. Available online: http://municipalitiesintransition.org/wpcontent/uploads/sites/3/2019/09/MiT-Framework_version-1.1-April-2018-to-be-published.pdf (accessed on 12 December 2019).

80. Bockelbrink, B.; Priest, J.; David, L. Sociocracy 3.0-A Practical Guide. Available online: https://sociocracy30. org/_res/practical-guide/S3-practical-guide-ebook.pdf (accessed on 22 November 2018).

(C) 2020 by the authors. Licensee MDPI, Basel, Switzerland. This article is an open access article distributed under the terms and conditions of the Creative Commons Attribution (CC BY) license (http://creativecommons.org/licenses/by/4.0/). 